University of Pennsylvania Carey Law School

Penn Law: Legal Scholarship Repository

Faculty Scholarship at Penn Law

1997

\title{
The Courtroom as Classroom: Independence, Imagination and Ideology in the Work of Jack Weinstein
}

Stephen B. Burbank

University of Pennsylvania Carey Law School

Follow this and additional works at: https://scholarship.law.upenn.edu/faculty_scholarship

Part of the Judges Commons, Legal Biography Commons, and the Legal Education Commons

\section{Repository Citation}

Burbank, Stephen B., "The Courtroom as Classroom: Independence, Imagination and Ideology in the Work of Jack Weinstein" (1997). Faculty Scholarship at Penn Law. 503.

https://scholarship.law.upenn.edu/faculty_scholarship/503

This Article is brought to you for free and open access by Penn Law: Legal Scholarship Repository. It has been accepted for inclusion in Faculty Scholarship at Penn Law by an authorized administrator of Penn Law: Legal Scholarship Repository. For more information, please contact PennlawIR@law.upenn.edu. 


\title{
THE COURTROOM AS CLASSROOM: INDEPENDENCE, IMAGINATION AND IDEOLOGY IN THE WORK OF JACK WEINSTEIN
}

\author{
Stephen B. Burbank*
}

This Article explores influences that have shaped Judge Weinstein's judicial behavior. The author argues that Weinstein's conception of the judicial role has been influenced in significant respects by his career as a law professor. Tracing continuities and discontinuities between the roles of a professor and a trial judge, the author concludes that Judge Weinstein manifests both the desire for intellectual autonomy and the consequent lack of regard for institutional accountability that are characteristic of the former role. The Article then seeks to evaluate the judge-centered approach to judicial independence it imputes to Judge Weinstein. The author contends that the desire to give free reign to his extraordinary intelligence and creativity plays a part in Judge Weinstein's pursuit or creation of the extraordinary in preference to the ordinary- "litigations" rather than cases-an interpretation that helps to explain certain inconsistencies in his judicial work. The author also considers the possibility that ideology plays a part in Judge Weinstein's approach to his role as a federal judge. He argues that there are three interrelated ideas that exercise a consistently powerful influence on Weinstein's judicial behavior and that may be thought ideological: access, communication and empathy. He concludes that the dichotomy between independence and ideology in Judge Weinstein's work may be false, because independence of a type-ethical individualism-is his overriding ideology. Although focusing on the work of Judge Weinstein, the Article suggests some general conclusions about independence and accountability in a trial judge, about judicial imagination, and about ideology.

\section{INTRODUCTION}

Academics above all others should understand this need for independence and imagination [in judges]. Whatever the curriculum may say, we each run our classrooms to satisfy our individual visions.

Jack B. Weinstein ${ }^{1}$

[L] ower federal courts ... lack the freedom of law professors to overrule the [Supreme] Court.

Stephen B. Burbank ${ }^{2}$

* David Berger Professor for the Administration of Justice, University of Pennsylvania. John Goldberg, Robert Gorman, Howard Lesnick, Leo Levin, Louis Pollak and Stephen Subrin read and provided helpful comments on a draft.

1. Jack B. Weinstein, After Fifty Years of the Federal Rules of Civil Procedure: Are the Barriers to Justice Being Raised?, 137 U. Pa. L. Rev. 1901, 1911 (1989) [hereinafter Weinstein, Barriers to Justice].

2. Stephen B. Burbank, Afterwords: A Response to Professor Hazard and a Comment on Marrese, 70 Cornell L. Rev. 659, 660 (1985). 
Thirty years is very nearly a career for many working people, or at least it was before age-discrimination legislation gave ordinary working people a taste of the security that the Constitution gives to Article III judges." It is thus a humbling thought that Jack Weinstein had distinguished careers as a teacher, scholar and law reformer before he took office (although, famously, neither ascended the bench nor donned the robe $^{4}$ ), let alone that he also served as a soldier. Indeed, the use of the past tense in connection with any of Jack Weinstein's careers is questionable. Although a federal judge for the past thirty years, he has continued to teach, to write-has any trial judge in our history produced as many articles and books? - and to advocate and participate in the hard work of law reform.

The books and articles that Jack Weinstein has written, together with his opinions, provide what some might call a "paper trail." If only because that expression may be thought to imply a destination, I prefer to see Weinstein's extrajudicial writings as windows into his mind, helping us better understand his judicial behavior, only fragments of which are preserved in published opinions. ${ }^{5}$

In a brief comment on one of Judge Weinstein's articles celebrating the fiftieth anniversary of the Federal Rules of Civil Procedure, ${ }^{6}$ I noted that " $[0]$ ne hears much these days about the independence of the federal judiciary... . [but] less about the independence of individual federal judges," and I voiced a suspicion that "Judge Weinstein's years in

3. See U.S. Const. art. III, § 1; Age Discrimination in Employment Act of 1967, 29 U.S.C. \$\$621-634 (1994).

4. See Jack B. Weinstein, Individual Justice in Mass Tort Litigation 91 (1995) [hereinafter Weinstein, Mass Tort Litigation] (preference to conduct "most nonjury work without a robe sitting in the courtroom at a table"). In this respect Judge Weinstein has followed the advice of Jerome Frank and the example of his predecessor on the district court bench, Julian Mack. See Jerome Frank, Courts on Trial 254-61 (chapter entitled "The Cult of the Robe") (1949). But see Richard A. Posner, Overcoming Law 121 (1995) ("The republican simplicity of manners-the 'I'm no better than the next guy' deportment - that most American judges affect is intended to be admired rather than to be taken seriously. Judges receive deference because they have power, and the power resides in their votes."); Linda S. Mullenix, Mass Tort as Public Law Litigation: Paradigm Misplaced, 88 Nw. U. L. Rev. 579, 591 (1994) ("As for me, I prefer judges in their robes, and on the bench.").

5. Most of Judge Weinstein's judicial behavior is not captured in opinions. See Letter from Jack B. Weinstein to Stephen B. Burbank (June 1 l, 1996) (on file with the Columbia Law Review) (“[M] ost of [my favorite procedural decisions] are oral. . . They are almost never transcribed unless an appeal is taken, which occurs only infrequently."). Such is generally the case with trial judges. See, e.g., Frank, supra note 4, at 222-24; Posner, supra note 4, at 112-14. Moreover, because of both the rhetorical function of opinions and publication practices that are neither comprehensive nor scientific, published opinions may give a distorted picture of the legal landscape. See Frank, supra note 4, at 165-85; Stephen B. Burbank, The Transformation of American Civil Procedure: The Example of Rule 11, 137 U. Pa. L. Rev. 1925, 1955-56 (1989).

6. See Jack B. Weinstein, The Ghost of Process Past: The Fiftieth Anniversary of the Federal Rules of Civil Procedure and Erie, 54 Brook. L. Rev. 1 (1988) [hereinafter Weinstein, Fiftieth Anniversary]. 
academe contributed more than deep learning to his career as a judge." 7 I also observed that his article "demonstrate[d] both the powerful vision of justice that has marked his career as a judge and the practical vision of politics that has marked his career as a scholar," but I questioned "whether the Judge has succeeded in reconciling those visions."

This Festschrift provides a welcome opportunity to pursue further the suggestion that Jack Weinstein's notions of judicial independence and of the judicial role have been shaped in part by, but are not always in harrnony with, his experience and knowledge as an academic. The view I take through the windows opened by his writings is that an important part of Weinstein the judge is Weinstein the law professor. I therefore consider his work as a whole with an eye to continuities and discontinuities between the roles of professor and federal judge. I am primarily interested in the first of the two desiderata in a judge that Weinstein himself identified and associated with academic life-independence. ${ }^{9}$ I then briefly take up the quality that he linked with independence-imagination ${ }^{10}$ - and a third quality that may be at war with independence, if not with imagination-ideology.

When seeking to draw inferences from the written record of the past, it is important to take account of the passage of time, the effects of both experience and role on substance, ${ }^{11}$ and the rhetorical demands of a particular role. In Jack Weinstein's case, that is only to say that the record is as complex as the man, which is reason enough to resist labels of the sort that recurrently debase public discourse about the federal judiciary. It is also reason enough not to draw too much from what is after all only a part, even if an important part, of a full and active life.

Still, in seeking to delineate some of the influences that have contributed to Weinstein's judicial behavior, I hope also to suggest some general lessons about independence and accountability in a trial judge, about judicial imagination, and about ideology. These are complex and difficult matters. Attempting to come to grips with them is critically important at a time when judges both state and federal are attacked, and in some jurisdictions may lose their offices, because of the decisions they make.

Mindful of Judge Weinstein's observation that "[p]roceduralists are of ten hot-blooded as well as long-winded," ${ }^{2}$ I shall attempt to be neither.

7. Stephen B. Burbank, The Chancellor's Boot, 54 Brook. L. Rev. 31, 31 (1988).

8. Id. at 32.

9. See Weinstein, Barriers to Justice, supra note 1, at 1911.

10. See id.

11. Judge Weinstein has explained such effects as follows:

As authority for this warning against attempts to use class actions in torts, the [1966 Advisory Committee Note to Federal Rule 23] cites an article I wrote as a law professor. As a judge I have been forced to ignore this indiscretion when faced with the practicalities of mass tort litigation. In the earlier 1960s we did not fully understand the implications of mass tort demands on our legal system.

Weinstein, Mass Tort Litigation, supra note 4, at 135.

12. Weinstein, Barriers to Justice, supra note 1, at 1904. 
I shall also attempt to avoid the "absurd ... notion that, because one finds fault in some ideas of men of genius, he should disregard all the rest." 13 I recognize how difficult it is to be a judge today, particularly a federal judge with Jack Weinstein's personality, life experiences, and belief structure. If I pause over certain aspects of his judicial behavior that I find problematic, it is to honor our shared commitment to the pursuit of knowledge. None of us would want to be emulated in every facet of our professional lives. All of us would be better off if more federal judges emulated more facets of Jack Weinstein's professional life.

\section{IndEPEndEnCE AND ACCOUntability}

In a mass tort case, a judge's failure to appreciate the reach and importance of his or her decisions is tantamount to abdication of responsibility. Much as the President steers the ship of state at the head of the executive branch, each federal trial judge, with respect to each case that comes before him or her, stands watch over the judicial branch. The trial judge is in most cases the final arbiter. If the trial judge fails to respond to the needs of the public, the only recourse is to appellate judges who are narrowly confined in matters of fact and who are usually in a less favorable position than the nisi prius judge to understand the full scope of a litigation. A rigid and unresponsive judiciary, blind to the needs of various communities and of society at large, is far more likely to cause an erosion of public confidence in legal institutions than a judiciary perceived as overly interested in resolving problems before it. ${ }^{14}$

No doubt it expands the ego of a judge to look upon himself as the guardian of the general future. But his more humble yet more important and immediate task is to decide individual, actual, present cases. ... Such judicial legislation as inheres in formulating legal rules is inescapable. But courts should be modest in their legislative efforts to control the future .... The future can become as perniciously tyrannical as the past. Posterity-worship can be as bad as ancestor-worship. ${ }^{15}$

Jack Weinstein brought to the bench an attitude towards independence that was shaped by his experience as an academic. Academic freedom and judicial independence are alike in some respects, including the fact that they exist to protect institutions. They also differ in critical respects. Whereas intellectual autonomy is central to the integrity of the academic enterprise, it can be inimical to the perceived legitimacy of the judiciary in a democracy. Jack Weinstein's writings-his opinions and particularly his books and articles-are a rich repository for the consideration of issues that are at the crossroads of judicial independence and

13. Frank, supra note 4 , at viii.

14. Weinstein, Mass Tort Litigation, supra note 4, at 92.

15. Frank, supra note 4, at 287-88 (quoting Aero Spark Plug Co. v. B.G. Corp., 130 F.2d 290, 295-96 (2d Cir. 1942) (Frank, J., concurring) (footnotes omitted)). 
accountability. Study of those writings suggests to me that Judge Weinstein is too much Professor Weinstein. I find evidence in his judicial and extramural work of insufficient attention to institutional (as opposed to individual) independence and, as a corollary, to the idea of, or mechanisms for ensuring, accountability. But those are my conclusions, and I reach them having enormous respect for Judge Weinstein's struggle with the "insoluble dilemma" of preserving legitimacy, while seeking to honor the "dominant needs and aspirations" of the times. ${ }^{16}$

\section{A. Academic Freedom and Judicial Independence}

Jack Weinstein forged his credentials and reputation as an academic in a world where professors enjoyed substantial freedom to teach and write what they chose, and where the tenure system provided structural protection for their intellectual independence. ${ }^{17}$ By the 1960s, in any American institution of higher learning worthy of the name, an attempt to dictate the content of teaching or writing would have been resisted fiercely and probably successfully. For in the absence of explicit contractual language, American courts were likely to order the parties' relations in accordance with the normative stance worked out when the state sought to control the academic enterprise:

The essentiality of freedom in the community of American universities is almost self-evident. No one should underestimate the vital role in a democracy that is played by those who guide and train our youth. To impose any strait jacket upon the intellectual leaders in our colleges and universities would imperil the future of our Nation. No field of education is so thoroughly comprehended by man that new discoveries cannot yet be made. Particularly is that true in the social sciences, where few, if any, principles are accepted as absolutes. Scholarship cannot flourish in an atmosphere of suspicion and distrust. Teachers and students must always remain free to inquire, to study and to evaluate, to gain new maturity and understanding; otherwise our civilization will stagnate and die. ${ }^{18}$

16. Archibald Cox, The Independence of the Judiciary: History and Purposes, $21 \mathrm{U}$. Dayton L. Rev. 566, 567 (1996).

The court must preserve its legitimacy and the ideal of law by invoking a majestic sense of continuity. At the same time, the law must coincide with the dominant needs and aspirations of its times. The dilemma is in soluble. . . The judge who persistently confuses law with his or her personal values also invites attacks upon judicial independence. In short, the risk to the independence of the courts is the Id.

politicization of the judiciary. It can be created on either side.

17. See, e.g., Ralph S. Brown \& Jordan E. Kurland, Academic Tenure and Academic Freedom, Law \& Contemp. Probs., Summer 1990, at 325, 328-31, 333-34 (examining the impact of tenure on academic freedom).

18. Sweezy v. New Hampshire, 354 U.S. 234, 250 (1957); cf. id. at 261-63 (Frankfurter, J., concurring) (contending that government must not intrude on academic freedom without "exigent and obviously compelling" reasons). 
There have been strains on the tenure system in recent years, the most troublesome of which have involved speech codes and attacks in the name of productivity. ${ }^{19}$ In each case, a rallying cry for change has been the need for accountability.

Tenured American professors are not only independent, but also largely unaccountable. It is true that professors must publish in order to qualify for tenure, and they may be responsive to peer pressure. Yet, once they have tenure, they may safely prefer the reflected glow of institutional glory to the court of scholarly opinion. ${ }^{20}$ Or at least they may do so if their salary, space and other similar perquisites are not dependent on the ability to secure grants. That is to say, the tenure system is generally thought to confer on prof essors much the same protection against diminution of compensation that Article III confers on federal judges. ${ }^{21}$

Among academics, law professors have long been, and they remain, singularly insulated from accountability. ${ }^{22}$ Once law professors have tenure, ${ }^{23}$ if they run out of ideas or for other reasons choose not to publish,

19. See, e.g., Matthew W. Finkin, Introduction to The Case For Tenure 1, 1-2 (Matthew W' Finkin ed., 1996) (defending tenure against such attacks); Cass R. Sunstein, Academic Freedom and Law: Liberalism, Speech Codes, and Related Problems, in The Future of Academic Freedom 93, 106-12 (Louis Menand ed., 1996) (evaluating universityimposed content-based restrictions on speech).

20. But see William Van Alstyne, Tenure: A Summary, Explanation and "Defense", in The Case For Tenure, supra note 19 at 3,3-4 (contending that universities may determine and apply standards of "adequate cause" so long as they do not abridge academic freedom or personal civil liberties).

Unlike federal judges, professors need not worry that their unpublished projects will appear on a list after three years. The Civil Justice Reform Act of 1990 (CJRA) requires the preparation of a semiannual report, available to the public, "that discloses for each judicial officer... the number and names of cases that have not been terminated within three years after filing." See 28 U.S.C. $\$ 476$ (a) (1994 \& Supp. I 1995). In its evaluation of experience under the CJRA, RAND's Institute for Civil Justice found that after the requirement went into effect, and although "the number of all civil cases pending . . . increased, ... the number of cases pending over three years . . . dropped by about 25 percent from its pre-CJRA level." James S. Kakalik, et al., An Evaluation of Judicial Case Management Under the Civil Justice Reform Act xxx (1996).

21. See American Ass'n of Univ. Professors, 1940 Statement Of Principles On Academic Freedom and Tenure, reprinted in Law \& Contemp. Probs., Summer 1990, at 407, 407 ("a sufficient degree of economic security to make the profession attractive to men and women of ability"); Letter from Robert A. Gorman, Professor, University of Pennsylvania Law School, to Stephen B. Burbank (March 6, 1997) (on file with the Columbia Law Review) (contending that " $[t]$ enure would be an inadequate protection for independent and controversial speech by academicians if salary could be whittled away as a reprisal").

22. Cf. Posner, supra note 4, at 112 ("It is the unique insulation of federal appellate judges from accountability that makes their behavior such a challenge to the economic analysis of law, and more broadly to the universalist claims of the economic theory of human behavior." (footnote omitted)).

23. In the old days it did not take much writing (or perhaps any) to secure tenure. Now, more is expected in that regard, but the absence of a community of scholars with shared interests (or values) - of a discipline of academic law-renders suspect both premises of "peer review." For a discussion of the importance of disciplines and 
the cost of salary increases foregone can be more than covered by consulting fees. And if they do choose to publish, whether or not they have run out of ideas, peer review will not usually get in their way.

If Judge Weinstein were still only a professor, it might be that, as a doctrinalist, he would be forced to confront "the epistemic shallowness of the enterprise." 24 But he has never been only a doctrinalist. ${ }^{25}$ More important, no law professor, or at least none who is really interested in law, need be "only a professor." As there are numerous opportunities to supplement academic compensation, so are there opportunities to build reputation and popularity among groups far more numerous and powerful than the professoriate. ${ }^{26}$ The classroom remains a good place to start. ${ }^{27}$

It may be harder to remove a federal judge from office for misconduct than to fire a tenured university professor, ${ }^{28}$ but that is a small point at which to stick. Notwithstanding storm clouds on the academic horizon, it is difficult to conclude that judges enjoy greater independence than professors. This is as it should be, because there are important dif-

"disciplinarity" to academic freedom, see Louis Menand, The Limits of Academic Freedom, in The Future of Academic Freedom, supra note 19, at 3, 3-20.

24. Posner, supra note 4 , at 88.

25. See, e.g., Vargas v. Keane, 86 F.3d 1273, 1281 (2d Cir. 1996) (Weinstein, J., concurring) (discussing results of questionnaire he distributed to jurors, which suggested that "jurors are not as sensitive to the nuances of various charges on reasonable doubt as judges and lawyers seem to be"); Jack B. Weinstein, Routine Bif urcation of Jury Negligence Trials: An Example of the Questionable Use of Rule Making Power, 14 Vand. L. Rev. 831, 847-52 (1961) [hereinafter Weinstein, Routine Bifurcation]; infra text accompanying notes $128-130$.

Our academics and ethicists seem to prefer library research to field research.

This preference is understandable since field work is so time consuming and expensive, but lack of it may lead to academic commentary having little relation to the real world. Should law professors have ethical obligations to resist becoming insulated and detached from the day-to-day realities of litigation and to produce work that can be better utilized by the public and the courts?

Weinstein, Mass Tort Litigation, supra note 4, at 274 n.34.

In the view of one scholar/critic, Judge Weinstein has not been immune to academic fads. See Mullenix, supra note 4 , at 583, 585 \& n.18.

26. In contrast, the opportunities for federal judges to supplement their incomes and to engage in extramural activities that could serve as alternative sources of reputation are seriously constrained. See Posner, supra note 4, at 137-38; Stephen B. Burbank, Is it Time for a National Commission on Judicial Independence and Accountability?, 73 Judicature 176, 177 (1990).

27. Law schools serve a profession. Some students become leaders of the bar, others judges, and still others politicians. As a result, not many institutions can afford to tolerate the neglect of teaching and of students that is sometimes, perhaps unfairly, associated with the liberal arts tradition and that some see as unfortunate baggage of law's interdisciplinary voyage.

28. See Posner, supra note 4, at 111 (suggesting that "pretty much the only thing that will get [an Article III judge] removed is criminal activity."). There is reason to doubt, however, whether in these days the "high hurdle" to removal of an Article III judge that Judge Posner refers to-which must be that of transaction costs-would protect judges engaging in some of the behavior he enumerates. See id. (mistreating staff; leaking confidential information to the press). 
ferences in the functions of independence and accountability in the two worlds. However, the relationship between individual freedom and independence seems not to be such a difference. Both the individual judge and the individual professor are protected so that an institution may flourish.

Academic freedom is linked to the birth of the modern university in nineteenth-century Germany. ${ }^{29}$ In this country, the notion was promoted to advance "not the absolute freedom of utterance of the individual scholar, but the absolute freedom of thought, of inquiry, of discussion and of teaching, of the academic profession." 30

Federal judicial independence is also first and foremost an institutional value, designed to protect the separation of powers and the rule of law. ${ }^{31}$ Article III of the Constitution vests judicial power in courts, not judges. ${ }^{32}$ Remembering that lower federal court judges owe the existence of their positions to congressional rather than constitutional choices should help focus attention on the institutional goals that service during good behavior and the guarantee of undiminished compensation were meant to further. ${ }^{33}$

29. See Walter P. Metzger, The 1940 Statement of Principles on Academic Freedom and Tenure, Law \& Contemp. Probs., Summer 1990, at 3, 14-15.

30. American Ass'n of Univ. Professors, General Report of the Committee on Academic Freedom and Academic Tenure, 1 Am. Ass'n U. Professors Bull. 17, 39 (1915), reprinted in Law \& Contemp. Probs., Summer 1990, at 393, 404-05 [hereinafter 1915 AAUP Report]; see also Thomas L. Haskell, Justifying the Rights of Academic Freedom in the Era of "Power/Knowledge," in The Future of Academic Freedom, supra note 19, at 43, 54 ("[The founders of the modern university] wanted to liberate individual practitioners ... from the dictates of their employers, not as an end in itself, but as a way of enhancing the authority of the entire community of practitioners." (footnote omitted)).

31. See Stephen G. Breyer, Judicial Independence in the United States, 40 St. Louis U. L.J. 989, 989 (1996) (identifying five components that together "combine to assure an independent judiciary that is the basis for a society in which people and the government behave according to rules of law, rather than according to the will or whim of powerful rulers."); Stephen B. Burbank, The Past and Present of Judicial Independence, 80 Judicature 117, 118 (1996).

32. See U.S. Const. art. III, \$1; Felix S. Cohen, Transcendental Nonsense and the Functional Approach, 35 Colum. L. Rev. 809, 843 (1935) ("Judges are human, but they are a peculiar breed of humans, selected to a type and held to service under a potent system of government controls. Their acts are 'judicial' only within a system which provides for appeals, rehearings, impeachments, and legislation."); Charles G. Geyh, Paradise Lost, Paradigm Found: Redefining the Judiciary's Imperiled Role in Congress, 71 N.Y.U. L. Rev. 1165, 1193 (1996).

33. It may be useful for certain purposes to distinguish between the institutional independence of the judiciary and the independence of an individual judge, as when federal judges impose discipline on a colleague. Yet, even when there is conflict within the judiciary that implicates judicial independence, the ultimate values to be served are those that preserve and protect the judicial branch as an institution. In other words, the protection of the institution may on occasion require vindicating the position of an individual judge who is in conflict with the institution's leadership for the time being. 
Academic freedom and accountability are in tension only to the extent that the latter threatens the "right to examine, question, modify or reject traditional ideas and beliefs." 34 Although an assistant professor experiences the "double-edged way" in which academic freedom operates, ${ }^{35}$ a tenured professor should be intellectually autonomous ${ }^{36}$ and in that sense unaccountable. ${ }^{37}$

Judicial independence and accountability may also be in tension, but not for the same reasons. Independence requires that judges be able to decide cases, find facts and say what the law is, free of both public pressure and private blandishment. Yet, acknowledging the need for law, including the law made by judges, to evolve with the society it serves, it is not the role of judges of inferior federal courts freely to "modify or reject [those] traditional ideas and beliefs" 38 that are captured in rules we call

Burbank, supra note 31, at 117; see also Report of the Nat'l Comm'n on Judicial Discipline and Removal 9-17 (1993) [hereinafter National Commission Report] (discussing constitutional issues affecting federal judicial independence and accountability).

34. Siveezy v. New Hampshire, 354 U.S. 234, 262 (1957) (Frankfurter, J., concur ring) (quoting Conference of Representatives of the Univ. of Cape Town and the Univ. of the Witwatersrand, The Open Universities in South Africa 10 (1957)); see also id. at 262-63 ("Dogma and hypothesis are incompatible, and the concept of an immutable doctrine is repugnant to the spirit of a university."). On the tension that may arise between individual and institutional academic freedom, see David M. Rabban, A Functional Analysis of "Individual" and "Institutional" Academic Freedom under the First Amendment, Law \& Contemp. Probs., Summer 1990, at 227, 280-300.

35. Menand, supra note 23, at 9 ("[ $\mathrm{N}]$ o one who is an assistant prof essor coming up for tenure is likely to feel a strong association between the experience and the concept of intellectual freedom.").

36. Academic freedom does not, however, give any professor the right to be institutionally autonomous, as by refusing to teach courses reasonably assigned, to serve on faculty committees, and the like. Such behavior is not grounds for removal of tenure unless egregious, to be sure, but there are other instruments of accountability, such as denial of a salary increase. The problem in contemporary law schools is that such measures mav not be effective.

37. This is not to deny "the immensity of the intellectual debt each of us owes to the disciplinarv matrix within which we work." Haskell, supra note 30 , at 76 . Nor is it to deny that the parents of academic freedom in this country-those who wrote the 1915 AALP Report, supra note 30- "associated the right of academic freedom with a duty on the part of the academic profession to police its ranks and rigorously uphold standards." Haskell, supra note 30 , at 57; see also id. at 60 (discussing necessity of peer review, conducted by prof essors rather than trustees or administrators). Nor still is it to deny that such remains a worthwhile goal today. See id. at 67 (" $[\mathrm{T}]$ he community of the competent cannot do its work of cultivating and authorizing sound opinion unless its members confront one another and engage in mutual criticism."). It is, however, to assert that policing is more difficult in a world of fragmenting and disintegrating academic disciplines, and that it is precisely in such a world that tenured professors are most likely to insist upon their autonomy.

38. Sueez), 354 L.S. at 262 (Frankfurter, J., concurring) (quoting Conference of Representatives of the University of Cape Town and the University of the Witwatersrand, The Open Universities in South Africa 10 (1957)). 
law. Stare decisis may not enshrine "immutable doctrine,"39 but neither may a federal trial judge be intellectually autonomous.

The stakes are different as well. As a result, although academic freedom only sporadically raises accountability issues, ${ }^{40}$ accountability is now and always will be central to the independence of the judiciary. ${ }^{41}$ Continuing public acceptance of a life tenured judiciary-its legitimacy in a democracy-depends upon continuing faith in the means by which judges are held accountable for their decisions.

\section{B. Judicial Accountability}

We should not forget that Justice Samuel Chase only narrowly escaped removal from office for partisan judicial behavior in 1805 or that, if the Senate had convicted him, the impeachment process might have become an acceptable instrument of policing unpopular judicial decisions. ${ }^{42}$ That it is not so regarded is rightly a cause of satisfaction. ${ }^{43}$ But it is no more an occasion for complacency than is the unacceptability of court-packing plans after President Franklin Roosevelt's failed effort in 1937, which, as I have noted elsewhere, "shar[es] with the trial of Justice Chase status as a defining moment in the history of federal judicial independence." +4 To the contrary, having resolved to forswear blunt instruments to hold our judges accountable for their decisions, we have a greater interest in ensuring the adequacy of the tools that remain.

As suggested above, the rule of law is a potentially powerful norm of accountability that, when applied to the lawmaking of judges, requires fidelity to the past. In that aspect the rule of law ideal reflects the view that, in order to have a government of laws and not men, the judiciary must either follow or explain departures from precedent, "applying a

39. Id.

40. I happen to believe that academic freedom is important to the wellbeing of American society, but not even rank self-interest could cause me to equate its importance with the preservation of federal judicial independence. Speech codes are a transient phenomenon; the quest for greater productivity may last longer, but, except as part of an attack on the tenure system, it poses only an indirect threat to academic freedom.

41. As the National Commission [on Judicial Discipline and Removal] recognized, these concepts need not and should not be at war with one another.

The Constitution provides for both as part of the system of checks and balances.

It should be impossible, except perhaps for a lawyer, to think about one without thinking about the other. Both tend to ensure the respect and confidence necessary to the effectiveness of the federal judiciary in our representative democracy. Neither alone would do so.

Burbank, supra note 31, at 118; see also National Commission Report, supra note 33, at $1-26$.

42. See Breyer, supra note 31, at 990.

43. See Burbank, supra note 31, at 118. But see infra text accompanying note 229.

44. Burbank, supra note 31 , at 120 . 
continuity of inherited legal principles, even though it strives to cater to the dominant needs of its times." 45

Whatever comfort one may take from the shared backgrounds, educational and professional experiences, and socialization of federal judges, ${ }^{4 h}$ the rule of law is not self-enforcing. Moreover, it is not a norm that obviously fosters accountability in much of the work of those courts that "are the heart of court-house government," ${ }^{77}$ the trial courts. Finally, trial courts lack the safety of numbers-they lack both the greater capacity of a plural court to ensure conformity and also the availability of the dissenting opinion to express nonconformity. ${ }^{48}$

The common law tradition of public access to court proceedings is another means by which courts are made accountable and the legitimacy of the judiciary is preserved. The protection it affords is perhaps most important at the trial court level, where first instance decisions are made, many of which are effectively the final-although of ten not publishedword. ${ }^{49}$ In the Age of Settlement, when compromises extend to traditional litigation values, public access may be thought expendable. ${ }^{50}$

Thus, at the end of the day, the most important warrant of accountability for the decisions of most federal judges-other than their own professional self-discipline-is the realistic prospect of appellate review. ${ }^{51}$ That is not good news. In 1949, Jerome Frank derided "the illusory notion that upper courts can offset all the failings of the trial judges," 52 and thus he disputed a major premise behind Felix Cohen's notion that

45. Cox, supra note 16, at 580. For an interesting recent unpacking of the various meanings of "The Rule of Law," see generally Richard H. Fallon, Jr., "The Rule of Law" as a Concept in Constitutional Discourse, 97 Colum. L. Rev. 1 (1997).

46. But cf. National Commission Report, supra note 33, at 2 ("[A]ccepted standards of judicial conduct became contestable as a result of changing societal expectations and of the increasing heterogeneity of the federal judiciary."); Weinstein, Mass Tort Litigation, supra note 4, at 156, 162 (acknowledging costs, including instability and unpredictability, of reliance on equitable discretion of trial courts). Compare W'einstein, Barriers to Justice, supra note 1, at 1902 ("enormous peer pressure and common background" have prevented discretion from breeding "unacceptable differences in practice among federal district courts and judges") with Burbank, supra note 5, at 1929-30 n.23 (disputing Judge Weinstein's attempts to minimize disuniformity).

47. Frank, supra note 4, at 222; see infra text accompanying notes 83-86.

48. Diversity does not have the same centrif ugal force when fidelity to precedent is in question as it does when standards of conduct are concerned. Cf. supra note 46 (diversity of judiciary calls into question previously accepted norms of judicial conduct). The rule of law is safer in a plural court than in the hands of an individual judge.

49. See supra note 5 and accompanying text.

50. See Cincinnati Gas \& Elec. Co. v. General Elec. Co., 117 F.R.D. 597, 60()-02 (S.D. Ohio 1987), aff d, 854 F.2d 900, 905 (6th Cir. 1988) (barring access to summary jury trial on the ground that it is a settlement device).

51. See National Commission Report, supra note 33, at 1-2.

52. Frank, supra note 4, at 223; see also id. at 33, 57. 
judges serve "under a potent system of governmental controls." 53 Almost fifty years later, the prospect of appellate review is rarely realistic, and there is reason for concern about the quality of review when it occurs. ${ }^{54}$ Through a combination of moves-some small, some big, some whose consequences were intended, ${ }^{55}$ some unintended ${ }^{56}$ - we have created a situation in which trial courts wield tremendous power and only with difficulty can be held accountable for their decisions. We may have put federal judicial independence at risk by depriving ourselves of the main structural check against abuse of power at the trial level.

\section{Independence and Accountability in the Work of Jack Weinstein}

As a judge, Jack Weinstein has been "true to an inner core of responsibility" and thus has been willing "sometimes [to] risk, or even court, reversal to make certain that the appellate courts, the bar, academia and the public are fully aware that there is a strong opposing moral view." 57 From the unanswerable opinion Judge Weinstein wrote (on remand) demonstrating why Rule 11 sanctions ordered by the Court of Appeals were inappropriate, ${ }^{58}$ to his opinions protesting the dehumanizing ef-

53. Cohen, supra note 32, at 843; see also Frank, supra note 4, at 148-55 (discussing social, economic, political and professional influences on trial judges, especially as compared with appellate judges).

54. See generally W'illiam M. Richman \& William L. Reynolds, Elitism, Expediency, and the New Certiorari: Requiem for the Learned Hand Tradition, 81 Cornell L. Rev. 273 (1996) (arguing that effective right to appeal error no longer exists and that the quality of the work of the courts of appeals has deteriorated)

55. Federal Rule of Civil Procedure 52(a) provides in pertinent part that "[f]indings of fact, whether based on oral or documentary evidence, shall not be set aside unless clearly erroneous, and due regard shall be given to the opportunity of the trial court to judge of the credibility of the witnesses." Fecl. R. Civ. P. 52(a). A 1985 amendment added the words, "whether based on oral or documentary evidence," thereby insulating from reversal all findings of fact not clearly erroneous. See 471 U.S. 1155, 1158 (1985).

56. See Stephen C. Yeazell, The Misunderstood Consequences of Modern Civil Process, 1994 Wis. L. Rev. 631, 646-48. "Today the two tiers have become uncoupled. Trial courts work with ever-more-elaborate procedural tools, but appellate courts have not correspondingly increased their supervisory powers. The result is greater independence for trial courts." Id. at 641; see also infra text accompanying notes 83-86.

57. Jack B. Weinstein, Remarks in Symposium, Nazis in the Courtroom: Lessons from the Conduct of Lawyers and Judges Under the Laws of the Third Reich and Vichy, France, 61 Brook. L. Rev. 1121,1156 (1995) [hereinafter Weinstein, Nazis].

58. See Eastway Constr. Corp. v. City of New York, 637 F. Supp. 558 (E.D.N.Y. 1986) (demonstrating errors in the Court of Appeals' interpretation of Rule 11, both as to the standard for imposing sanctions and also as to the allocation of responsibility between trial and appellate court for selecting a sanction). Unfortunately, the Court of Appeals insisted on answering, however fecklessly, increasing the $\$ 1,000$ sanction that Judge W'einstein had imposed on the client to a $\$ 10,000$ sanction on the client and attorney. See Eastway Constr. Corp. v. City of New York, 821 F.2d 121 (2d Cir. 1987). It was consideration of th is case that prompted my initial thoughts about the influence of academia on Judge W'einstein. See supra text accompanying note 7 . 
fects of sentencing guidelines, ${ }^{59}$ he has used his powerful mind and seemingly inexhaustible energy to advocate his interpretations of existing laws and, where reinterpretation was not possible, to advocate for change.

Surely, this is the type of federal judge we should want, whatever our political views. Dilemmas have two horns, and the rule of law ideal cannot require us always to stick on one of them. ${ }^{60}$ To that extent we should agree with Judge Weinstein that " $[r]$ isk-for-risk, . . . a thinking, informed judge is far less dangerous than one pickled in his own, ever-so-ethical views." 61 And that is a very considerable extent, because it concedes to a federal trial judge the freedom (if not assigning the responsibility) to question and criticize laws, whether statutory or judge made, that are unjust or perhaps simply foolish.

Agreement with these sentiments of Judge Weinstein also requires that we be willing to tolerate occasional open refusals by a trial judge to follow the law as it is generally understood. ${ }^{62}$ This is a highly controversial proposition that requires elaboration. I refer to "occasional" refusals for both practical and normative reasons. Practically, it is a rare legal rule that admits of no doubt and hence of no room for maneuvering around an unjust or nonsensical result. As Judge Weinstein has observed, "[t]here are many techniques used by our courts to avoid and circumvent dubious and immoral precedents." ${ }^{33}$ Normatively, frequent judicial disobedience by trial judges would exhaust courts of appeals. Far more important, it could precipitate a constitutional crisis in which judicial independence would be the loser.

59. See, e.g., United States v. Shonubi, 962 F. Supp. 370 (E.D.N.Y. 1997); United States v. Cordoba-Hincapie, 825 F. Supp. 485 (E.D.N.Y. 1993); infra text accompanying note 111 (for further discussion).

60. See supra note 16 .

61. Jack B. W'einstein, Limits on Judges' Learning, Speaking and Acting-Part ITentative First Thoughts: How May Judges Learn?, 36 Ariz. L. Rev. 539, 562 (1994).

62. It may be important to distinguish between settled doctrine and a rule or interpretation recently announced by a court of appeals. In the Eastway case, Judge Weinstein and the Court of Appeals were disputing the proper interpretation of a recently amended (1983) Federal Rule of Civil Procedure and one, moreover, that seemingly conferred discretion on the trial judge as to the choice of a sanction. See Eastway, $637 \mathrm{~F}$. Supp. at 566-69, 584; supra note 57 and accompanying text. More than just Judge W'einstein's evidently superior understanding of the relcvant legal landscape in that case inclines me to the view that, in general, district judges should have greater freedom to insist that courts of appeals really mean what they say about a new law. Particularly when Supreme Court review is only a theoretical possibility, dialogue between the courts of appeals and the district courts is important for legal development.

63. W'einstein, Nazis, supra note 57, at 1155; see also id. at 1156 ("Precedent can be distinguished on many grounds as, for example, by characterizing the 'rule' as dictum, and by finding parallel lines of authority."); Jack B. Weinstein, Litigation Seeking Changes in Public Behavior and Institutions-Some Views on Participation, 13 U.C. Davis L. Rev. 231, 233 (1980) (jurisdictional and related concepts may appear to be inflexible but "sometimes they are soft around the edges and can be adjusted to achieve a sensible substantive result"). 
I refer to "open refusals" because I expect a trial judge to be candid about, and take responsibility for, the nature and extent, as well as the impact in a particular case, of a departure from the law as generally understood. For, as Professor Weinstein recognized, "there is no one but his fellow judges who can stop him when he proposes to stray beyond those "limits which precedent and custom and the long silent and almost indefinable practice of other judges . . . have set to judgemade innovations." "64 Moreover, as Judge Weinstein has observed in an article urging the importance of judicial review of administrative action, "our public hearings and written opinions ... keep the system honest. .. This is one of our most important protections against injustice and abuse of power." 65 Judge Weinstein was apparently not talking about the "system" in which he works, but his point is equally valid as applied to "a completely independent judiciary." 66

We do not need Judge Posner to tell us that "[j]udges don't like to be reversed," and his chosen focus on appellate judges colors the assertion that "aversion to reversal does not bulk large in the judicial utility function." 67 The willingness openly to "risk, or even court, reversal," 68 is, however, what separates that which I have provocatively called "judicial disobedience" from judicial nullification.

If one agrees with this assessment, certain aspects of the judicial work of Jack Weinstein may cause concern from the perspective of judicial independence and accountability. Before turning to these concerns, it bears repeating that, taken as a whole, Judge Weinstein's work represents the finest traditions of an independent federal judiciary. To read his 1984 article on social security disability cases, for example, is to share a record of judicial courage and determination, one that not only bore fruit for individual litigants who had the good fortune to end up in Judge Weinstein's courtroom, but also resulted in a change in national policy through sustained criticism. ${ }^{69}$

64. Weinstein. Routine Bifurcation, supra note 25, at 837 (omission in original) (quoting Benjamin Cardozo, The Nature of the Judicial Process 103 (1921)).

65. Jack B. Weinstein, Equality and the Law: Social Security Disability Cases in the Federal Courts, 35 Syracuse L. Rev. 897, 912 (1984) [hereinafter Weinstein, Sucial Security Disability Cases].

66. Id; see also Frank, supra note 4, at 288 ("Judicial candor with the public, I think, is the only practice consonant with democracy."); id. at 289 (encouraging courts to overturn undesirable precedent openly because "“[a] judiciary that discloses what it is doing and why it does it will breed understanding'” (quoting William O. Douglas, Stare Decisis, 49 Colum. L. Rev. 735, 754 (1949))).

67. Posner, supra note 4, at 118. For a discussion of the "judicial utility function," which refers to judges' preferences, or what they try to maximize, as judges, see id. at $117-26$. 57.

68. Weinstein, Nazis, supra note 57 , at 1156 ; see also supra text accompanying note

69. See W'einstein, Social Security Disability Cases, supra note 65, at 917 (suggesting that improper pressures by the national administration were weighing against Social Security disability benefit claimants); City of New York v. Heckler, 578 F. Supp. 1109 , 
There is no doubt that Jack Weinstein has shown himself to be the sort of judge that Professor Weinstein encouraged our system to seek in its judicial appointments: "mature [individuals] ... who understand intimately legal problems in their social and economic contexts, and who have the assurance to be both generous and courageous." 70

The three possible problems I see in Judge Weinstein's work from this perspective relate to (1) standards by which he determines not to follow the law as it is generally understood, (2) failure to take responsibility for some of his departures from those laws, and (3) lack of respect for accountability within the judiciary.

1. Standards for Judicial Disobedience. - Assuming that our system can tolerate occasional open refusals by trial judges to follow the law as it is generally understood (or that occasional open refusals may be essential to the system's health), frequent instances of judicial disobedience would present grave practical and normative problems. For this reason, there is an obvious need for limiting principles or standards to guide and restrain judges in choosing the occasions for disobedience.

Judge Weinstein recognized the problem in a discussion of jury nullification. Although claiming that " $[t]$ he heritage of refusing to obey laws regarded as unjust in their operation is honored today within all branches of the federal government, often for the 'good of the Republic," ${ }^{\prime 1}$ Judge Weinstein acknowledged that "[t]he difficulty with any tendency to ignore laws is that whether a particular law is unjust may depend entirely on the view of the beholder."72 In the context of jury nullification, he took comfort from "procedural safeguards and requirements of group decisionmaking." 73 Similar safeguards may not be available, and there is no such general requirement, for the work of federal trial judges. ${ }^{74}$

1124-25 (E.D.N.Y.), aff d, 742 F.2d 729 (2d Cir. 1984) (declaring the Social Security Administration's psychiatric review policy illegal).

70. Jack B. Weinstein, Trends in Civil Practice, 62 Colum. L. Rev. 1431, 1433 (1962) [hereinafter Weinstein, Trends]. It was confidence that Judge Weinstein's generosity extends to his critics, see Burbank, supra note 7 , that persuaded me to accept the invitation to participate in this celebration.

71. Jack B. W'einstein, Considering Jury "Nullification": W'hen May and Should a Jury Reject the Law to Do Justice, 30 Am. Crim. L. Rev. 239, 243 (1993) [hereinaf ter W'einstein, Jury' Nullification].

72. Id.

73. Id. at 245 .

74. See Act of Aug. 12, 1976, Pub. L. No. 94-381, 90 Stat. 1119 (codified at 28 U.S.C. $\$ 2284$ (1994)) (abolishing most three judge district courts); see also Judith Resnik, Managerial Judges, 96 Harv. L. Rev. 374, 424-31 (1982) (arguing that case management techniques of trial judges threaten to erode traditional due process saf eguards). Note, however, that one provision of the recently introduced Hyde bill would require that applications for injunctive relief (on the ground of unconstitutionality) against a state law adopted by referendum be heard, on an expedited basis, by a court of three judges, with direct appeal to the Supreme Court. See H.R. 1252, 105th Cong. $\$ 2$ (1997). 
What, then, are the standards that guide Judge Weinstein when he refuses to follow the law as it is generally understood? We may safely infer that he is one of those district judges who "have been known to nullify when, for example, they seek to escape the rigors of guideline sentencing or when the outcome of a trial totally offends their sense of justice."75 Nor do I think it unreasonable to include him among those judges who occasionally "stretch the law to some extent out of sympathy for the litigants and a sense of justice."76

The principle or standard for judicial disobedience emerging from Judge Weinstein's extramural writings is not much of a limitation, to the extent that it turns on the individual judge's desire for flexibility, sympathies or "sense of justice." 77 Judge Weinstein believes that "[e]ach American judge is individually beholden to the people and our conscience through the Constitution,"78 and that "a previously enunciated rule cannot, and should not, prevent an individual American judge from following the Constitution and what he or she considers its moral imperatives."79 It may be a long way from the Constitution to its moral imperatives and further still to an individual judge's sense of justice, par-

75. Weinstein, Jury Nullification, supra note 71, at 243; see infra text accompanying notes $107-111$.

76. Weinstein, Jury Nullification, supra note 71 , at 246; see also, e.g., In re DES Cases, 789 F. Supp. 552, 572 (E.D.N.Y. 1992) ("Given the Hymowitz court's decision to forgo joint and several liability, a DES plaintiff's full recovery would be frustrated if all manufacturers for pregnancy use could not be brought into court."), appeal dismissed, 7 F.3d 20 (2d Cir. 1993); Jack B. Weinstein, Limits on Judges' Learning, Speaking, and Acting: Part II Speaking and Part III Acting, 20 U. Dayton L. Rev. 1, 33-34 (1994) [hereinafter, Weinstein, Limits on Judges II \& III]; infra note 103 and accompanying text (discussing In re DES Cases); infra text accompanying note 89 (discussing Agent Orange).

This may also be an appropriate vantage point from which to view In re Repetitive Stress Injury Cases, 142 F.R.D. 584 (E.D.N.Y. 1992), rev'd, 11 F.3d 368 (2d Cir. 1993). In addition to chiding Judge Weinstein for "substitut[ing] a discussion of so-called mass torts for precise findings as to what are the 'common questions of law and fact' justifying consolidation pursuant to" Rule 42 of the Federal Rules of Civil Procedure, 11 F.3d at 373, the Court of Appeals noted that the factors favoring consolidation spoke to the "convenience of only one side"-the plaintiffs. Id. at 374 .

Note that the examples of "stretching" Judge Weinstein gave in the article quoted in the text- "landlord-tenant disputes or evictions for mortgage defaults"-are not exactly the staple of federal district judges. Weinstein, Jury Nullification, supra note 71, at 246.

77. Weinstein, Jury Nullification, supra note 71, at 246; see also Weinstein, Mass Tort Litigation, supra note 4, at 171 ("some felt sense of appropriateness"); Weinstein, Social Security Disability Cases, supra note 65, at 899-900 ("almost certain intuition, based on . . . knowledge of the law and life, that an injustice has been done").

78. Weinstein, Nazis, supra note 57, at 1154; see also Jack B. Weinstein, The Limited Power of the Federal Courts of Appeals to Order a Case Reassigned to Another District Judge, 120 F.R.D. 267, 285 (1988) [hereinafter Weinstein, Limited Power to Reassign] ("One of the great strengths of the federal judicial system has been the strong sense of independent power and responsibility of each federal judge to protect the Constitution and laws of the United States.").

79. Weinstein, Nazis, supra note 57, at 1156. 
ticularly if "[j]udges can ignore neither monstrous nor routine injustices."

2. Taking Responsibility for Judicial Disobedience. — I have sought to keep separate, and it may be significant that Judge Weinstein apparently does not distinguish between, refusal to follow the law as it is generally understood-what I have called "judicial disobedience"-and nullification. ${ }^{81}$ The value of the distinction, if any, lies in the existence of an institutional check on fidelity to the law in one case and the lack of any such check in the other.

According to this view, the jury in a criminal case engages in nullification if its acquittal results from refusal to follow the trial judge's instructions as to the governing law or if it consciously distorts the facts so as to avoid the reach of the law it has been given. But a federal trial judge commits a qualitatively different act if he or she refuses to follow the law as it is generally understood, so long as it is done openly and so long as there is a realistic prospect of appellate review. Judicial disobedience, in other words, entails willingness to pay the price of reversal. $\$ 2$

As previously discussed, it is hard to maintain that appellate review still provides effective structural assurance of judicial accountability. ${ }^{83}$ Not only have we abandoned a key check on the equitable discretion of federal trial judges by restricting interlocutory appeals, ${ }^{84}$ but we have broadened the domain of their discretion as to facts. ${ }^{85}$ Perhaps even more important, we have opened vast new vistas for the exercise of unreviewable discretion, and hence of power, by permitting, indeed encouraging, trial judges to become actively involved in settlement. ${ }^{86}$

Much has been written about the Agent Orange litigation, in which Vietnam veterans sued chemical manufacturers, claiming that the herbicide by which the litigation is known caused a host of diseases and conditions from which they suffered. Peter Schuck's book, ${ }^{87}$ together with Richard Marcus's review essay, 88 prompt numerous questions about Judge Weinstein's handling of the litigation, howsoever much one may

80. Id.

81. See W'einstein, Jury Nullification, supra note 71, at 243, 246.

82. Cf. Martin Luther King, Jr., Letter from Birmingham City Jail (Apr. 16, 1963), reprinted in A Testament of Hope: The Essential Writings of Martin Luther King, Jr. 289, 294 (James Melvin Washington ed., 1986) ("One who breaks an unjust laiv must do it openly, lovingly . . . and with a willingness to accept the penalty.").

83. See supra text accompanying notes $51-56$.

84. See Jack B. Weinstein \& Jonathan B. Wiener, Of Sailing Ships and Seeking Facts: Brief Reflections on Magistrates and the Federal Rules of Civil Procedure, 62 St. John's L. Rev. 429, 433 (1988) [hereinafter Weinstein \& Wiener, Magistrates]; Yeazell, supra note 56 , at $660-64$.

85. See supra note 55 .

86. See Yeazell, supra note 56, at 656-60; Stephen B. Burbank, The Costs of Complexity, 85 Mich. L. Rev. 1463, 1483-87 (1987) (review essay).

87. Peter H. Schuck, Agent Orange on Trial: Mass Toxic Disasters in the Courts (1986).

88. Richard L. Marcus, Apocalypse Now? 85 Mich. L. Rev. 1267 (1987) (review essay). 
admire the imagination and determination with which he obtained for the plaintiffs a settlement providing money and other benefits to which they were not entitled under the existing substantive law. ${ }^{89}$

Judge Weinstein's opinions on choice of law ${ }^{90}$ and governmental immunity ${ }^{91}$ also cause concern. Professor Schuck has aptly described the choice of law opinion, in which Judge Weinstein conjured up a "federal or a national consensus law of manufacturer's liability, government contract defense and punitive damages," 92 as a combination of "prestidigitation and rank insubordination," 93 but he has also ventured that it was "redeemed only by the manifest wisdom and fairness of his position." 94 With respect-to both Judge Weinstein and Prof essor Schuck-I cannot agree. For, as Professor Schuck also notes, Judge Weinstein did his best to insulate his "insubordination" from judicial review. ${ }^{95}$ The same was

89. See Weinstein, Mass Tort Litigation, supra note 4, at 11 ("The fact that the science did not support a viable cause of action did not warrant ignoring those cries from the heart for justice."); id. at $62,85-86,152$. For a detailed account of the settlement negotiations in Agent Orange, see Schuck, supra note 87, at 143-67.

90. In re "Agent Orange” Prod. Liab. Litig., 580 F. Supp. 690 (E.D.N.Y. 1984).

91. In re "Agent Orange" Prod. Liab. Litig., 580 F. Supp. 1242 (E.D.N.Y.), mandamus denied sub nom. In re United States, 733 F.2d 10 (2d Cir.), appeal dismissed, 745 F.2d 161 (2d Cir. 1984).

92. In re "Agent Orange" Prod. Liab. Litig., 580 F. Supp. at 713.

93. Schuck, supra note 87, at 130; see also Larry Kramer, Choice of Law in Complex Litigation, 71 N.Y.U. L. Rev. 547, 561-64 (1996).

The opinion partook of "prestidigitation" because it eliminated the choice of law problems that would have made class certification impossible under Rule 23 of the Federal Rules of Civil Procedure by assuming a "national consensus law" that simply did not exist.

Conjure as he might, no "national consensus law" existed on these issues. Significantly, he neither cited a case establishing that it did exist nor said what the content of that law was or even how one might go about divining it. That, he coyly observed, was "a subject for another memorandum"; his own opinion was merely "preliminary" and "provisional," "a first general guide to the parties of the court's present thinking," one that was always "subject to refinement and change."

Schuck, supra note 87, at 130 (quoting In re Agent Orange Pred. Liab. Litig., 597 F. Supp. 740, 845-47 (E.D.N.Y. 1984)).

The opinion partook of "rank insubordination" because, Judge W'einstein's attempted distinctions notwithstanding, it was inconsistent with an earlier Court of Appeals opinion holding that federal common law did not apply to Agent Orange, see In re "Agent Orange" Prod. Liab. Litig., 635 F.2d 987, 993 (2d Cir. 1980), which was law of the case. See Schuck, supra note 87 , at $128-30$.

94. Schuck, supra note 87 , at 130 .

95. By characterizing his opinion as provisional, Judge Weinstein "practically immunized his highly questionable ruling from appellate court review." Id. at 131. 
true of his governmental immunity opinion. ${ }^{96}$ The strategy worked; 97 the case was settled, and Judge Weinstein's individual vision of justice was served.

It is not clear, however, that the system of justice was well served. It is no secret that trial judges may wish to insulate their decisions from reversal on appeal and that there are many ways in which they may try to do so. If we are permitted to make normative judgments about such practices, rather than simply accept them as part of a utility function, ${ }^{98}$ we should perhaps draw some distinctions. We may, for instance, be more comfortable with a trial judge who takes self-protective action out of concern that all of the time and effort devoted to a trial will be wasted because of a disagreement about the admissibility of an item of evidence, or that the appellate court cannot accurately grasp the facts from the cold record, than we are with a situation like Agent Orange. If so, the reason is probably found in the judge's attitude toward, and efforts to abide by, the governing law.

In Agent Orange Judge Weinstein, pursuing the goal of settlement, applied what he knew was not generally understood as the law, and did everything he could to make sure that the train he was conducting was not derailed by the Court of Appeals. ${ }^{99}$ That is not a refusal; it is an evasion. It is not judicial disobedience, but nullification: the act of a "completely independent" judge who has sought to make the rest of the judiciary irrelevant and any protection against "abuse of power" 100 impos-

96. Professor Schuck described how Judge Weinstein shielded the decision from review:

Noting once again that his opinion was only "preliminary" and "tentative," designed merely to "assist the parties in preparing for trial," he closed by inviting the government to "renew its motion to dismiss at any time." This invitation, however, could not have been seriously intended. Indeed, when the government shortly thereafter and on several occasions asked Weinstein to reconsider or certify an immediate appeal on the issue, he summarily rejected the request; the gorernment, he insisted, must stand trial on May 7, only two months hence, unless a higher court intervened.

Id. at 136 (citation omitted).

97. The government sought and was denied mandamus, and its appeal was dismissed as premature. See In re "Agent Orange" Prod. Liab. Litig., 580 F. Supp. 1242 (E.D.N.Y.), mandamus denied sub nom. In re United States, 733 F.2d 10 (2d Cir.), appeal dismissed, 745 F.2d 161 (2d Cir. 1984). Judge Weinstein was not successful, however, in his efforts to "dragoon the government into the [settlement] negotiations." Schuck, supra note 87, at 149 .

98. See supra text accompanying note 67.

99. See Schuck, supra note 87 , at 178-79 (describing Judge Weinstein's role in settlement, and his desire to avoid appeal). The fact that the Agent Orange settlement (like many settlements) "creat[ed] in effect a new rule of substantive law," Weinstein, Mass Tort Litigation, supra note 4 , at 86 , does not excuse distortion of the substantive law as a means to broker settlement. Cf. Jack B. Weinstein, Some Reflections on the "Abusiveness" of Class Actions, 58 F.R.D. 299, 301-02 (1973) [hereinafter Weinstein, Class Actions] ("[It is] quite unwise to slip into important changes in substantive law on the happenstance that a suit is biought by a class rather than by an individual claimant.").

100. See supra text accompanying note 65. 
sible. In this respect the Agent Orange litigation seems a far cry from the tort system Judge Weinstein once described and, notwithstanding its defects, compared favorably with administrative systems because it was "out in the open and independent of government abuse."101

Agent Orange was a rare and unusual case, and one's reaction to its irregularities may be colored by Judge Weinstein's accomplishment, not just in securing money for Vietnam veterans who were in need, but in creating a structure that has produced benefits far beyond the dollars paid by defendants. ${ }^{102}$ But Judge Weinstein has not confined techniques that raise troublesome independence and accountability issues to Agent Orange.

It is perhaps more difficult to accept that Judge Weinstein's ends justified his means when, in more ordinary litigation, he required a corporate defendant (one among many) to defend a lawsuit on a theory of personal jurisdiction radically at odds with Supreme Court precedent, knowing that appellate review was unlikely and that the case would probably settle. ${ }^{103}$ The theory was the stuff of a law review article-a creative one at that. ${ }^{104}$ It was (or would have been if the defendant had settled) consequential not because it won acceptance in the marketplace of ideas, nor because it survived the gauntlet of appellate review, but as a result of something that looks uncomfortably like brute force.

As Felix Cohen observed, the "decision that is 'peculiar' suffers erosion-unless it represents the first salient manifestation of a new social force, in which case it soon ceases to be peculiar."10.5 At times Judge Weinstein seems to want to have his cake and eat it too: to be able to effect progressive change in the law through the intellectual force of his opinions without paying the price of (perhaps only temporary) rebuff

101. Weinstein, Mass Tort Litigation, supra note 4, at 169.

102. See id. at 104-06.

103. See In re DES Cases, 789 F. Supp. 552 (E.D.N.Y. 1992), appeal dismissed sub nom. In re DES Litig.. 7 F.3d 20 (2d Cir. 1993). The case did settle, but the defendant kept in, the successor to a California manufacturer of DES, refused to participate and secured a dismissal for want of prosecution when the plaintiff declined to present evidence. Thereafter, an attempt to take an appeal from Judge W'einstein's order on jurisdiction fell afoul of the rule that a judgment winner lacks standing to appeal. See DES Litigation, 7 F.3d at 23 .

104. Judge Weinstein has said about DES Cases:

Recently, I had an opportunity to employ some of my views on jurisdiction, acquired while working with the law school classes I taught on mass torts. In In re DES Cases, I took a position that was inconsistent with recent Supreme Court opinions, though not, I thought, with underlying principles.

W'einstein, Limits on Judges II \& III, supra note 76, at 33 (footnote omitted).

For a critique, see Allan R. Stein, Survey of Erie/Federal Common Law Cases and Personal Jurisdiction Cases, 1992 Newsletter of AAIS Section on Conflict of Laws (American Ass'n of Law Schs., W'ashington, D.C.), at 39-44.

105. Cohen, supra note 32 , at 843 . 
that is a cost of the rule of law. He seeks the "freedom of law professors to overrule the [Supreme] Court." 106

Finally on the subject of taking responsibility for judicial disobedience, another recent case-United States v. Londono-suggests that Judge Weinstein has difficulty distinguishing between the ordinary and the extraordinary. ${ }^{107}$ It also reveals the extent of his ingenuity in insulating the results of his work, if not the reasoning behind them, from appellate scrutiny. The judge's eloquently and persuasively stated objections to the Sentencing Guidelines are well known. Indeed, he has used the effort by unnamed judges "to escape the rigors of guideline sentencing" 108 as one specific example of judicial nullification.

Yet, one must wonder whether concern for the supposed infertility problems of a convicted defendant is sufficient reason to confect a sentence that not only flouts the Sentencing Guidelines but seems calculated to take the defendant outside of the jurisdiction (through court-ordered deportation) before there can be appellate review. ${ }^{109}$ As a result of this case, even one who agrees with Judge Weinstein's 1988 article disputing the power of a court of appeals to order that a case be assigned to another trial judge on remand ${ }^{110}$ can better understand the opposing view. ${ }^{111}$

3. Lack of Respect for Accountability Within the Judiciary. - Judge Weinstein is a very bright, learned, and self-assured person-brighter, more learned, and more self-assured than all but a handful of the Article III judges who sit, or could conceivably sit, in review of his work. His assertion that " $[\mathrm{n}]$ o federal judge worth his salt cares about a reversal, because he invariably knows in his heart that he was right and the higher court wrong," "12 therefore rings true to a scholarly audience, which was the audience he was addressing. But the remark was not seriously intended ${ }^{113}$ and, in any event, is hard to square with Judge Weinstein's attempts to avoid appellate review, if not with his judge-centered theory of

106. Burbank, supra note 2 , at 660; see also supra text accompanying note 2 .

107. 100 F.3d 236 (2d Cir. 1996).

108. Weinstein, Jury Nullification, supra note 71 , at 243 ; see also supra text accompanying note 75 .

109. See Londono, 100 F.3d at 238.

110. See Weinstein, Limited Power to Reassign, supra note 78. When he wrote the article, Judge Weinstein had not himself "been subject to such an order." Id. at 267.

111. In Londono, the Court of Appeals directed that "further proceedings be assigned to a different judge," 100 F.3d at 242, noting that the "district court's handling of this case has several troubling aspects," id., and "makes an exorbitant claim on appellate resources." Id. at 243.

Londono surely made even more delicious the recent opportunity Judge Weinstein had, and took, to demonstrate that a reduced sentence ordered by the Court of Appeals, although "desirable as a matter of policy and fairness," was the result of a "technique and rationale... of dubious validity." United States v. Shonubi, 962 F. Supp. 370, 371 (E.D.N.Y. 1997).

112. Weinstein, Social Security Disability Cases, supra note 65, at 897.

113. Here is the entire passage. I leave it to you whether Judge Weinstein was serious: 
judicial independence. To his credit, and quite characteristically, Judge Weinstein has frankly identified questions concerning the nature of judicial independence under the Constitution, and in particular whether "an independent judge [is] independent from his fellow judges or only from encroachment by the legislature and executive."114 His work leaves no doubt about his answer to that question.

Judge Weinstein's theory of independence, according to which every federal judge is accountable "to the people and [his or her] conscience through the Constitution," 115 seems to leave little room for formal institutional responses to the misconduct of a federal judge. Or so I interpret Judge Weinstein's assertion that 1980 legislation ${ }^{116}$ that was designed to provide a supplement to the impeachment process within the judiciary, ${ }^{117}$ was "in large part unconstitutional." 118 In matters pertaining to judicial accountability, Judge Weinstein is a strict constructionist, parsing statutes and denying claims of the inherent power of appellate courts in a fashion and with an attitude quite different from that which characterizes his own exercises of power. ${ }^{119}$

Indeed, although Judge Weinstein has acknowledged that effective appellate review is necessary to prevent "judicial despotism," "120 in recent years he appears to have come to regard courts of appeals as sources of "outside interference," or worse, "threats to the independence of fed-

But I regret to say that the titles of scholar and judge are incompatible. Judges cannot be scholars. If they were to try, as a scholar would, to understand the full complexity of every case, their decisions would never be timely. All that work-a-day judges like myself can do is to mingle whenever possible with scholars and students like yourselves in the hope that some of your knowledge and insight will rub off. No federal judge worth his salt cares about a reversal, because he invariably knows in his heart that he was right and the higher court wrong. But when a law review article or student note says he was mistaken, then he worries.

Id

114. Weinstein, Limited Power to Reassign, supra note 78, at 272.

115. Weinstein, Nazis, supra note 57, at 1154 .

116. See 28 U.S.C. $\$ 372$ (c) (1994). For a discussion of the 1980 Act, see Stephen B. Burbank, Procedural Rulemaking Under the Judicial Councils Reform and Judicial Conduct and Disability Act of 1980, 131 L. Pa. L. Rev. 283 (1982).

117. See National Commission Report, supra note 33, at 83.

118. Weinstein, Limited Power to Reassign, supra note 78, at 272 . It was not helpful to the independence of the judiciary for Judge Weinstein, as chief judge of a district court, simply to assert that an act of Congress was unconstitutional, let alone one that seeks to enhance the accountability of the judiciary. This is not to say that discussion and debate of such questions is inappropriate. See generally Harry T. Edwards, Regulating Judicial Misconduct and Divining "Good Behavior" for Federal Judges, 87 Mich. L. Rev. 765 (1989) (arguing that in matters not involving impeachable or criminal conduct judicial selfregulation is proper approach to uphold the tradition of judicial independence); Burbank, supra note 26, at 226-27 (disagreeing with Judge Edwards on whether Congress has a role to play in handling judicial misconduct falling short of impeachable conduct).

119. See generally Weinstein, Limited Power to Reassign, supra note 78 (questioning both inherent and statutory authority of an appeals panel to order that a case be reassigned upon remand).

120. Id. at 280 (quoting H.R. Rep. No. 50-942, at 4 (1888)). 
eral trial judges." That is, in any event, how he recently characterized interlocutory appeals, lumping them with the practice of ordering reassignment on remand. ${ }^{121}$

\section{Imagination and Ideology}

What accounts for these problematic aspects of the work of a great judge? The record, like the man, is too complex to afford an easy answer or perhaps any answer that will gain wide assent. Even if I am correct that Judge Weinstein remains Professor Weinstein in his approach to questions of independence and accountability, that is an insufficiently nourishing account of the behavior in question. I therefore consider normative justifications of a judge-centered approach to independence that Judge Weinstein himself has offered. I also consider explanations that are suggested by, but that may ultimately confound, the economic theory of judicial behavior.

\section{A. Imagination (Power)}

Trial judges have much to learn from [William] James. . . . With his marked poetic insight, which made him the despair of sedate, "classical," psychologists, he went far in exploring the jungles of the human mind. Judging, especially in trial courts, calls for such poetic insight. For poetry, which involves synthetic imagination, gives "an inclusive understanding of situations" in a way that "analytic reason" cannot. ${ }^{122}$

Academics tend to prize creativity more than they do learning, and they prize most of all the two in combination. When Jack Weinstein was a professor, academic law was a recognizable discipline; its orientation was doctrinal, and if only because of that orientation, scholars who could deploy their creativity and learning in directions that were thought to have practical payoffs were especially esteemed. Professor Weinstein was such a scholar.

As humbling as Jack Weinstein's multiple, various and continuing careers may be, ${ }^{123}$ consider what he accomplished before he became a

121. See Weinstein \& Wiener, Magistrates, supra note 84, at 433 \& n.19; cf. W'einstein, Fif tieth Anniversary, supra note 6, at 25 (noting that statutory limitations on intermediate appeals are in part responsible for an increase in "plaintiffs' capacity to enforce substantive rights"). Compare the far more sanguine view of courts of appeals espoused by Prof essor Weinstein in approving "[ $\mathrm{t}]$ aking new evidence and considering new theories of law on appeal ... so long as the litigants are notified and have an opportunity to advocate their views on the matter." Weinstein, Trends, supra note 70, at 1443 . Even then, however, he noted the danger "that the shift of responsibility upward will reduce the prestige of the lower courts and lead to a failure to assume responsibility by trial judges in cases in which they should face up to hard decisions." Id.

122. Frank, supra note 4, at 397 (footnotes omitted).

123. See supra text accompanying note 4 . 
judge. In only fifteen years ${ }^{124}$ he became one of the country's foremost scholars in both civil procedure and evidence and in his spare time helped to solve New York's motor vehicle problems, ${ }^{125}$ rewrote New York's Civil Practice Act, ${ }^{126}$ and started work on the first comprehensive reform of the law of evidence in the United States. ${ }^{127}$

Representative of Professor Weinstein's scholarship in this period is a 1961 article he published on bifurcation of jury negligence trials. ${ }^{128}$ The article is striking because Weinstein was so far ahead of most of his contemporaries in recognizing, and seriously engaging, the substantive impact of procedure and its implications for court rulemaking. It is also noteworthy because it reflects the fruits of rare commodities (in 1961 or 1997), ${ }^{129}$ comparative civil procedure ${ }^{130}$ and the use of empirical data. ${ }^{1.31}$ Like his other work, the article reveals a powerful and restless mind at work, refusing to be cabined by either conventional wisdom or conventional techniques.

Skip from 1961 to 1997, and from the work of Professor Weinstein to the work of Judge Weinstein. Presiding over related civil and criminal fraud cases, Judge Weinstein used "an integrated civil settlement and a criminal restitution order . . . to assure maximum recovery by the victims with minimum transactional costs." ${ }^{32}$. Although the Judge asserted that "[c] ombining criminal and civil proceedings, or aspects of those proceedings, is not novel," the references in support of that proposition are to articles discussing the procedural systems of Sweden and France. ${ }^{133}$ That is because the idea for the procedure Judge Weinstein devised was "sparked in part" by an international conference on comparative civil jus-

124. Weinstein joined the Columbia Law School faculty in 1952 and became a judge in 1967.

125. From 1952 to 1954, Weinstein was counsel to the New York Joint Legislative Committee on Motor Vehicle Problems.

126. From 1955 to 1958 Weinstein was Reporter of the Advisory Committee on Practice and Procedure of the New York State Temporary Commission on Courts, and from 1963 to 1966 he was a member of the Advisory Committee on Practice of the New York Judicial Conference.

127. Prof essor W'einstein was appointed to the Advisory Committee on Rules of Evidence of the Judicial Conference of the Lnited States in 1965, and he continued service (until 1975) after his appointment as a district judge.

128. See W'einstein, Routine Bifurcation, supra note 25.

129. See Burbank, supra note 5, at 1928 (deploring failure to base procedural rules on empirical foundation); John H. Langbein, The Influence of Comparative Procedure in the United States, 43 Am. J. Comp. L. 545, 545 (1995) (discussing disturbing fact that "[ $\mathrm{t}$ ]he study of comparative procedure has little following in academia, and virtually no audience in the courts or legal policy circles").

130. See Weinstein, Routine Bifurcation, supra note 25, at 831 n.* (noting that article grew out of work on German procedural devices).

131. See id. at 847-52; see also supra text accompanying note 25.

132. United States v. Cheung, 952 F. Supp. 148, 148 (E.D.N.Y. 1997).

133. Id. at 150 . 
tice reform that he had attended in Florence in 1996.134 But the Judge also brought to bear on the problem his extraordinary experience in, and his perspectives on, class actions, conducting proceedings that could be "likened to Rule 23 fairness hearings ... not only to inform the court, but to assure the victims (many of whom were unaware of the workings of the American justice system) that they were being treated fairly." 135

Not content to implement a strikingly innovative approach inspired in part by his forays among scholars, Judge Weinstein, ever the scholar himself, identified potential "unnecessary problems and possible injustices" in the coordinated conduct of civil and criminal proceedings. ${ }^{136}$ All of this in an opinion of eight double-spaced pages!

For Judge Weinstein, as for Professor Weinstein, a major value of independence-academic and judicial-inheres in the "latitude for experimentation" it affords. ${ }^{137}$ It is this quality that prompted him to liken the courtroom to a classroom. ${ }^{138}$ According to this view, both legal progress and the capacity to attract to the bench intelligent and creative people require that individual judges not feel that they are "straight-jacketed by the current consensus interpretation of ambiguous national rules." 139 It is, in other words, a view that essentially equates independence with discretion, and hence with power, ${ }^{1+0}$ and imputes to it values that relate both to legal development and to the utility function of judges:

The reality is that judicial and administrative discretion pervade our system at all levels. Such flexibility invites creativity, stimulates innovation, and in good measure is responsible for the attraction that law holds for our brightest young minds. To the public, however, it is undoubtedly a source of frustration and cynicism. ${ }^{1+1}$

This bears some resemblance to Judge Posner's explanation of the reasons why "judges adhere to stare decisis but not rigidly," $1+2$ an explanation that is, however, ultimately unsatisfying:

[I]f there is no felt choice, there is no pleasure in choosing. That may be why so many district judges held the federal sen-

134. Letter from Jack B. Weinstein to Stephen B. Burbank (January 14, 1997) (cops on file with the Columbia Law Review).

135. Cheung, 952 F. Supp. at 151

136. Id. at 150. Judge Weinstein discusses problems arising from the prohibition on trial court involvement in plea negotiations and from the need to assure that the defendant has adequate resources to support his or her family if circumstances change after sentencing. See id. at 150-51.

137. Weinstein, Barriers to Justice, supra note 1, at 1911.

138. See supra text accompanying note 1.

139. Weinstein, Barriers to Justice, supra note 1, at 1911; see also supra text accompanying note 1 .

140. See Burbank, supra note 86, at 1470 ("Those responsible for procedural reform know that discretion is an instrument of power.").

141. Jack B. Weinstein, Justice and Mercy-Law and Equity, 28 N.Y.I. Sch. L. Rev: 817, 818 (1984) [hereinafter Weinstein, Justice and Mercy]

142. Posner, supra note 4 , at 125. 
tencing guidelines unconstitutional. They believed that the guidelines would turn criminal sentencing, formerly an area of almost unlimited district-judge discretion, into a process of mechanical, but laborious, computation. ${ }^{143}$

The notion that power is important to an understanding of judicial behavior is not restricted to those who take an economic approach to law. ${ }^{14 t}$ But Judge Posner has provided an interesting summary of recent work that analyzes judges' power "as a source of satisfaction, or even of exhilaration, akin to that experienced by creative people." 145 His discussion suggests that just as "[a]rtists impose their aesthetic vision on society[,] judges impose their political vision on society." 146

Judge Posner's application of economic theory to the judiciary, and the literature on which he relies, ${ }^{147}$ are primarily concerned with appellate (collegial) courts. It is this focus that leads to his assertion that judges impose "their political vision on society. . . mainly through the precedential force of their decisions, since a single decision rarely has a great impact." 148 And the same focus suggests a "trade-off between the loss of power that results from judges' following their predecessors' decisions rather than innovating and the loss of power that results if, by refusing to follow their predecessors' decisions, ... they reduce the likelihood that their successors will follow their decisions." 149

The calculus is different for trial judges, particularly in the age of managerial judging, aggregation, and settlement. ${ }^{150}$ If Agent Orange has taught us-and that includes Judge Weinstein-anything, it is that single "litigations," 151 if not single decisions, can have a great impact indeed. Moreover, trial judges bent on maximizing their power are not likely to

143. Id. (footnote omitted); cf. Jack B. W'einstein, A Trial Judge's Second Impression of the Federal Sentencing Guidelines, 66 S. Cal. L. Rev. 357, 366 (1992) [hereinafter Weinstein, Federal Sentencing Guidelines] ("But use of the guidelines does tend to deaden the sense that a judge must treat each defendant as a unique human being. The present system contributes to the bureaucratic mentality described by Hannah Arendt in her analysis of the "banality of evil." (footnote omitted)(quoting Hannah Arendt, Eichmann in Jerusalem (2d ed. 1964))).

144. See, e.g., Stephen B. Burbank, Procedure and Power, $46 \mathrm{~J}$. Legal Educ. 513, $513-15$ (1996). See generally Burbank, supra note 86, at 1471-76.

145. Posner, supra note 4 , at 121 .

146. Id.

147. Seee. e.g., Lewis A. Kornhauser, Modeling Collegial Courts I: Path-Dependence, 12 Int'l Rev. I. \& Econ. 169, 180-85 (1992) (arguing that collegiality among appellate judges determines the path of the law).

148. Posner, supra note 4, at 121.

149. Id. (footnote omitted).

150. See generally Resnik, supra note 74 (assessing increased power of trial judges resulting from pretrial managerial judging, which is rarely reviewable); Yeazell, supra note 56 (contending that trial courts are equipped with increasingly extensive procedural tools, yet appellate courts have not accordingly increased their supervisory powers).

151. "My practice is generally to concentrate on litigations." I.etter from .Jack B. Weinstein to Stephen B. Burbank (June 11, 1996) (copy on file with the Columbia Law Review). 
pause long over the trade-off posited in Judge Posner's discussion, if they perceive it as applicable to them at all. Finally, it seems equally true of trial as of appellate judges that, although criticism for flouting precedent is a cost, it "may well be outweighed by the gain ... from changing policy in the direction [the judge] desires." 152

The theory that treats judges' power "as a source of satisfaction, or even of exhilaration, akin to that experienced by creative people," 153 may have some explanatory force when applied to the work of Jack Weinstein. Not only is that theory consistent with a number of his own statements about the judicial function, it also helps to explain behavior of Judge Weinstein that is otherwise puzzling.

I have noted that Judge Weinstein does not always distinguish ordinary from extraordinary cases for the purpose of judicial disobedience or nullification. ${ }^{154}$ Professor Mullenix has seen in Judge Weinstein's attempt to assimilate mass tort litigation to public law litigation the desire to "intervene assertively in mass tort cases to impose court-ordered solutions, just as he did in school desegregation and mental health cases." 15.5 Both phenomena may reflect the desire to maximize opportunities for judicial behavior that is itself extraordinary and that affords extraordinary satisfaction.

This seems a more plausible explanation of Judge Weinstein's attempts to consolidate stress disorder cases than the efficiency rationale he offered after he was reversed by the Court of Appeals. ${ }^{156}$ For, as the Court of Appeals suggested, mass torts can become a "self-fulfilling prophecy" 157 at the hands of a judge for whom the intellectual challenges of complexity may sometimes obscure its costs. ${ }^{158}$

152. Posner, supra note 4 , at 122 .

153. Id. at 121 .

154. See supra text accompanying notes $103-111$.

155. Mullenix, supra note 4, at 580; see also id. at 581-82 (comparing mass torts with "public law" constitutional litigation of the 1960s).

156. Case by case disposition seems to me to be unsuitable for what may be many thousands of stress disorder cases. . . . The Court of Appeals has not. in my opinion, sufficiently considered the efficiency of having one decision on the science issues instead of, as in Bendectin, many decisions by trial and appellate courts all over the country. Expenses to plaintiffs are increased since each must pay a substantial filing fee. Control of discovery by many magistrate judges instead of one is duplicative and less effective; the work of many judges and magistrate judges is needed to control discovery'.

W'einstein, Mass Tort Litigation, supra note 4, app. at 352-53 (citations omitted). Judge Weinstein had not previously been well knøwn as a proponent of efficiency-based rationales for procedural solutions to litigation problems. See Jack B. Weinstein, Procedural Reform as a Surrogate for Substantive Law Revision, 59 Brook. L. Rev. 827, 829 (1993) [hereinafter W'einstein. Procedural Reform]; Weinstein, Barriers to Justice, supra note 1, at 1906; infra text accompanying notes 171-172.

157. In re Repetitive Stress Injury Litig., 11 F.3d 368, 374 (2d Cir. 1993).

158. See generally Burbank, supra note 86 (discussing costs of complex litigation). 
The possibility that Judge Weinstein's utility function drives him to seek (or create) the extraordinary in preference to the ordinary-"litigations" rather than cases-may also help to explain apparent inconsistencies that are surprising in one so intelligent and so pragmatic. Professor Schuck discussed inconsistencies between the Judge's treatment of individual (opt-out) plaintiffs and members of the class in Agent Orange, which included letting the individuals suffer "premature dismissal" that the Judge had recognized as problematic for the class. ${ }^{159}$ Judge Weinstein also is not consistent in that he fails to recognize that, just as premature aggregation in a class action may seriously prejudice the ability of those who have been injured to establish a right to recover under the governing substantive law, so may other forms of aggregation, such as consolidation. ${ }^{160}$

It cannot be, however, that Judge Weinstein's judge-centered theory of independence and accountability reflects only the Judge's desire to exercise power in order to maximize purely personal satisfaction. Nor is that the only possible interpretation of Judge Posner's discussion of the economic analysis of judicial behavior. Recall that the satisfaction or exhilaration he posited derived from "judges impos[ing] their political vision on society." 161 This suggests that we should also consider whether ideology plays a part in Judge Weinstein's approach to his role as a federal judge. In doing so, we may be led to agree with Professor Geyh's critique of public choice theory. As he points out, "self-interest explains judicial conduct only if self-interest is defined broadly to account for otheroriented behavior. With such a definition, however, the public choice model becomes tautological and explains nothing." 162

\section{B. Ideology}

Because there are so many ordinary judges, and because anti-intellectualism, democratic egalitarianism, and suspicion of officials run deep in the American soul, there is even a cult of ordinariness in judging. Exceptionally able judges arouse suspicion of having an "agenda," that is, of wanting to be something more than just corks bobbing on the waves of litigation or umpires calling balls and strikes. Some judges have had political agendas, but there is no correlation between being exceptionally able and having such an agenda. ${ }^{163}$

159. See Schuck, supra note 87, at 182-83, 242-43.

160. See Weinstein, Mass Tort Litigation, supra note 4, at 352-53. But see In re Breast Implant Cases, 942 F. Supp. 958, 961 (E.D.N.Y. \& S.D.N.Y. 1996) (denving motion for summary judgment because scientists were still developing relevant information); infra text accompanying note 180 .

161. Posner, supra note 4, at 121 ; see also supra text accompanying note 146 .

162. Geyh, supra note 32, at 1216 (footnote omitted); see also id. at 1213 \& n.251 (contrasting public choice theory of judicial decision-making with judges ideological motivations).

163. Posner, supra note 4 , at 110. 
Having previously described the way in which Judge Weinstein painted "the personality of our legal system" 164 as a "combination of personal politics and wishful thinking," 165 and being anxious to avoid misunderstanding, I should define my terms. ${ }^{166}$ Judges are bound to have beliefs about both the appropriate role of, and appropriate policies or goals for, government, some of which they are bound to translate into law. That is not only because judges are human. ${ }^{167}$ It results as well from the fact that in our system "the line between law and policy ... is blurred [because] [m]any cases cannot be decided by reasoning from conventional legal materials [and] [s] uch cases require the judge to exercise a legislative judgment." 168

A judge's political beliefs, his or her policy preferences, should not cause concern unless they hold sway with such power as to be impervious to adjudicative facts, competing policies, or the governing law as it is generally understood. When an individual's belief system about social needs or aspirations is that powerful, it seems fair to speak of ideology. ${ }^{169}$ And on this understanding, ideology is revealed as the enemy of judicial independence. ${ }^{170}$

One way an individual judge's policy preferences can be, or can become, "impervious" to law is through nullification. We should, therefore, consider whether conflicts in recent years between Judge Weinstein and the Court of Appeals turn on matters not of independence but of ideology. That seems a possible interpretation of his attempts to insulate from appellate review his work in Agent Orange and other cases, at least if one also credits his statements about appellate review as a necessary check on

164. Weinstein, Fif tieth Anniversary, supra note 6, at 29.

165. Burbank, supra note 7 , at 32-33.

166. See Cohen, supra note 32, at 836 ("A definition is in fact a type of insurance against certain risks of confusion.").

167. When all is said and done, we must face the fact that judges are human.

That should not dismay those of us who cherish democracy. For in a democracs it is imperative never to forget that public of fices are, of necessity, held by mere men, who, of course, have human foibles. It is only where government officials are deemed to be semi-divine that people have any excuse for ignoring the ineluctable personal factor in government.

Frank, supra note 4 , at 410 (footnote omitted).

168. Posner, supra note 4 , at 131.

169. See Edward Shils, The Concept and Function of Ideology, in 7 International Encyclopedia of the Social Sciences 66 (David L. Sills ed., 1968). I recognize that one person's "ideology" is another's "perspective" or "world-view." Howard Lesnick, The Wellsprings of Legal Responses to Inequality: A Perspective on Perspectives, 1991 Duke L.J. 413, 413-14 \& n.3. That is why I am careful to define "ideology" for these purposes.

170. [W] e put judicial independence at risk when we appoint to the bench those who are prisoners of a character, a physical or mental disability, or of any other human failing that, in a judge, may render the fruits of the judicial process irrelevant. . . . $[A]$ ccording to this view, because ideologues of any political stripe are not truly independent, a conscious effort to secure their appointment to the federal bench would be an attack on judicial independence.

Burbank, supra note 31, at 120 (footnote omitted). 
abuse of power. This interpretation may also be consistent with Judge Weinstein's description of appellate concern over the possible costs of aggregating civil cases as "a form of closing the courthouse door that represents a shifting of the balance of substantive law in favor of defendants." 171 Finally, it may help to explain his assertion that "[a]ppellate courts are showing an increased tendency to lean toward defendants in [mass tort] cases." 172

My study of Jack Weinstein's work suggests that there are three ideas that exercise a consistently powerful influence on his judicial behavior, so powerful that they may at times lead him to neglect competing policies or to depart from the law as it is generally understood, and in that sense may be thought ideological. These three ideas-access, communication, and empathy-are related, perhaps interdependent.

1. Access. -

The erection of barriers to court access under the guise of procedural efficiency seems misguided and shortsighted: it will burden the weak and the aggrieved unfairly, and it ultimately will undermine the legitimacy of the legal system which most of these "reformers" hold dear. ${ }^{173}$

Judge Weinstein has a passionate commitment to access to the courts for those who are aggrieved, a commitment consistently reflected in his decisions as a judge and in his extrajudicial writings. It was alertness to this value that led him to refuse to apply a state ethical rule on responsibility for the costs of litigation when doing so would impede the purposes of the federal class action rule. ${ }^{174}$ It was in part concern about access for those seeking to assert state law claims that influenced his opinion on federal preemption under the Federal Insecticide, Fungicide and Rodenticide Act (FIFRA). ${ }^{175}$ And he has voiced a similar concern about access in response to appellate decisions restricting the ability of federal district judges to consolidate cases under Rule 42.176

171. Weinstein, Mass Tort Litigation, supra note 4, at 353 .

172. Id. at 174 n.3; cf. id. at 223 n.32 (arguing that success of aggregation in mass tort litigation depends on personalities of participants).

173. Weinstein, Barriers to Justice, supra note 1 , at 1906

174. See County of Suffolk v. Long Island Lighting Co., 710 F. Supp. 1407, 1413-15 (E.D.N.Y. 1989), aff d, 907 F.2d 1295 (2d Cir. 1990); accord Rand v. Monsanto Co., 926 F.2d 596 (7th Cir. 1991); cf. Stephen B. Burbank, State Ethical Codes and Federal Practice: Emerging Conflicts and Suggestions for Reform, 19 Fordham Urb. L.J. 969, 970-72 (1992) (discussing conflicts between federal procedural rules and local district court rules that incorporate provisions of state codes of professional conduct).

175. See Burke v. Dow Chem. Co., 797 F. Supp. 1128, 1132 (E.D.N.Y. 1992) ("Too ready a tendency to declare the state protective shield replaced by the still somewhat spotty federal protections will leave many injured persons without recourse.") (discussing FIFRA, 7 L.S.C. \$\$ 136-136y (1994)).

176. Fed. R. Civ. P. 42. See supra text accompanying note 172. These examples hardly do justice to Judge Weinstein's commitment to access. For additional examples, see, e.g., Weinstein, Social Security Disability Cases, supra note 65, at 935 (discussing Eastem District (ivil Litigation Fund and pro bono panel). 
I share Judge Weinstein's commitment to preserving access to the courts for those who are aggrieved and his discomfort with experiments to restrict court access that may themselves be the product of ideology. ${ }^{177}$ I also acknowledge that, taking a broader view of the federal court system today, some may regard his efforts to ensure access for those who feel aggrieved as, if not a cry in the wilderness, then a brave attempt to stem a tide of heartlessness and greed masquerading as efficiency. Nonetheless, I worry that Judge Weinstein may be insufficiently attentive to (1) the problems that defendants may confront in achieving effective access to the judicial process at the trial level and to (2) the fact that access should include access to appellate review.

Judicial disobedience in promoting, and subsequently insulating from appellate review, ${ }^{178}$ judicially confected and brokered settlements is hard to square with a commitment to access for all. A recent decision by Judge Weinstein and Judge Baer, coordinating the management of breast implant cases in the Eastern and Southern Districts of New York, raises a similar concern. ${ }^{179}$ They refused to grant a defense motion for summary judgment as to some (the most serious) plaintiffs' claims, which were admittedly not adequately supported, on the ground that scientific evidence might be forthcoming to shore them up. At the same time, and over defendants' objection, they severed for trial other claims for which adequate proof might be available. ${ }^{180}$

Many years ago, Judge Weinstein wrote that "[c]lass actions favor plaintiffs. There is no doubt about it." 181 Yet, as Professor Yeazell has demonstrated, that has not always been true, and recent developments in class action practice, together with recently proposed amendments to Rule 23, reveal the potential of the class action to favor defendants as well. ${ }^{182}$ As Professor Yeazell also notes, these developments may augur genuine procedural neutrality. ${ }^{183}$

I recognize, of course, that many plaintiffs confront more substantial obstacles to court access than do many defendants. But "many" is not all. In any event, as I have argued elsewhere, "[n] either judges nor procedural reformers have a general charter to reform society, and broad-scale

177. See Burbank, supra note 5, at 1947-48 ("Theory is an irresponsible basis for lawmaking about something as important as access to court, and it is especially irresponsible when the lawmaking involves judicial amendment of a Rule [Rule 11] that, in part because of access concerns, only barely escaped the bright light of the democratic process.").

178. See supra text accompanying notes 87-101.

179. See In re Breast Implant Cases, 942 F. Supp. 958 (E.D.N.Y. \& S.D.N.Y. 1996).

180. See id. at 963.

181. Weinstein, Class Actions, supra note 99, at 300.

182. See Stephen C. Yeazell, The Past and Future of Defendant and Sertlement Classes in Collective Litigation, 39 Ariz. L. Rev. 687, 703 (1997).

183. See id. at 704 . 
social reform would be necessary to eradicate the non-neutral effects of many, and perhaps most, procedural rules." 184

"Procedural camouflage" 185 can be used to broaden, as well as to restrict, access, and I agree with Judge Weinstein that " $[\mathrm{t}]$ he public is entitled to be aware of and participate in the law reform process." 186 When the law in question is not a court rule, but rather judge-made law, participation requires effective access to the judicial process for all parties and proceedings that are open to the public. ${ }^{187}$ The "legitimacy of the legal system" 188 is equally at stake.

Finally, if we are concerned about the effect of inequality of resources as between plaintiffs (and/or their agents) and defendants (and/ or their agents) on access to court, as pragmatists we should also be concerned about the possible results of the same inequality on access to the legislature in effecting civil justice reform. The concern is that a perceived tilt by the courts toward plaintiffs may lead to legislation that blocks or seriously impedes access to court. As the Private Securities Litigation Reform Act of $1995^{189}$ demonstrates, perception in Washington does not depend upon facts. ${ }^{190}$

\section{Communication. -}

The judge should, it is submitted, expose himself or herself on a person-to-person basis to the emotional and other needs of the litigants. This proposition requires a shift from the traditional Anglo-American jurisprudential view that the common law judge is an oracle on high, muffled in the black robe of anonymity, uttering the law and deciding the facts without involvement. ${ }^{191}$

Communication is instrumental to Judge Weinstein's commitment to access for those who are aggrieved. He reaches out to hear from, and thus better understand the interests and concerns of, those who may be affected by judicial action. In so reaching out, Judge Weinstein serves

184. Burbank, supra note 86 , at 1473 .

185. Weinstein, Procedural Reform, supra note 156, at 829 .

186. See id.

187. Broadening access-for both plaintiffs and defendants-is in my view a powerful argument in favor of the current proposal to amend the federal class action rule to permit interlocutory appeals from certification decisions in the discretion of the court of appeals. See Proposed Amendments to the Federal Rules of Civil Procedure, 167 F.R.D. 559, 560, $565-66$ (1996).

188. Weinstein, Barriers to Justice, supra note 1, at 1906.

189. Pub. L. No. 104-67, 109 Stat. 737 (codified as amended in scattered sections of 15 U.S.C. and 18 U.S.C.).

190. Cf. Thomas E. Willging et al., An Empirical Analysis of Rule 23 to Address the Rulemaking Challenges, 71 N.Y.U. L. Rev. 74, 177-79 (1996) (noting differences between anecdotal evidence, relied on by Congress, and evidence from empirical study).

191. Weinstein, Mass Tort Litigation, supra note 4, at 9. 
both the dignity and participation values of litigation ${ }^{192}$ and, ultimately, the legitimacy of legal institutions. ${ }^{193}$

The rules of procedure provide a structured process for communications among the parties and the court. They also recognize the importance in some situations of participation by those who are not formally before the court, ${ }^{194}$ and in class actions, give the judge affirmative responsibility to provide them with an opportunity to be heard. ${ }^{195}$ With the advent of structural reform litigation has come a rich literature on both the need for the judge to transcend the traditional umpireal role and the difficulty of devising standards to guide the judge when fashioning, or considering a proposed, decree. ${ }^{196}$

Structural reform litigation and class actions are the exception, even if they garner a disproportionate amount of scholarly (and judicial) attention. But there is also a rich empirical literature on the experience of those who have been involved in dispute resolution processes, which indicates that for many people, satisfaction lies less in winning than in being fairly heard. ${ }^{197}$ Thus, in reaching out to those who may be affected by the decisions he makes, in ordinary and extraordinary cases alike, Judge Weinstein has again been ahead of many of his colleagues, and for that matter of much of the profession.

Horvever, just as communication is essential to Judge Weinstein's conception of access, so is it subject to the test of evenhandedness. Civil defendants have needs and concerns too, and they may have employees and stockholders to worry about. ${ }^{198}$ We should not assume that agency problems involving communication between lawyer and client are always

192. See Frank Michelman, The Supreme Court and Litigation Access Fees: The Right to Protect One's Rights (pt. 1, 1973 Duke L.J. $1153,1172-75$.

193. See Weinstein, Mass Tort Iitigation, supra note 4, at 13-14 ("In this time of increasing public alienation from lawyers and the law, the legitimacy of our legal institutions depends upon the individual's belief that he or she counts in the system and that we lawvers and judges are here to serve all the people."); see also id. at 56 (arguing that public confidence in our judicial svstem depends on our sustem's responsiveness to people's needs).

194. See Fecl. R. Civ. P. 19, 24.

195. Sce Fed. R. Civ. P. 23.

196. See, e.g., Abram Chayes, The Role of the Judge in Public Iaw Litigation, 89 Harv. L. Rev: 1281, 1288-1304 (1976); Susan P. Sturm, A Normative Theory of Public Law Remedies, 79 Geo. L.J. 1355, 1409-46 (1991).

197. See, e.g., Robert J. Maccoun et al., Alternative Adjudication: An Evaluation of the New Jersey Automobile Arbitration Program 62 (1988).

198. Judge Weinstein is aware of "the danger that a defendant without substantial fault may be driven into huge settlements or even put out of business by the quantity of attackers, if not their quality." Weinstein, Mass Tort Litigation, supra note 4, at 85 . It is striking, however, that this acknowledgment came in a discussion of the Agent Orange litigation, his approach in which he described as "essential, creating in effect a new rule of substantive law." Id. at 86; see also Mullenix, supra note 4, at 585 ("Missing from Judge W'einstein's notion of community is the defendant community, for example."). 
greater for plaintiffs than defendants. ${ }^{199}$ It thus may be a mistake for a "communicatarian" 200 to rely on defense lawyers to bring before the court all relevant perspectives in support of their legal contentions.

Moreover, when a judge reaches out to litigants in nontraditional ways, he risks misperception that can sabotage the admirable goal of using communication to foster the public's views about the legitimacy of the system. Those whose interests are opposed to the individuals or groups to whom the judge reaches out may equate communication with influence and come to believe that they have not been fairly treated.

Judge Weinstein created such problems a few years ago when he met on four occasions, on the record, with persons who claimed to have been injured by DES and their lawyers, a meeting at which, in the Judge's words, "[t]he women recounted tragic stories of how DES had affected their lives."201 In denying a motion to disqualify himself in the case of one of the women with whom he had met, Judge Weinstein explained that at the time he had been serving "in [a] settlement role," 202 and that it was then unknown that she would become a plaintiff in a case before him. Vigorously defending the "need for the court to communicate with the parties," 203 the Judge distinguished empathy and lack of impartiality, ${ }^{204}$ pointing out that in the meetings he had "noted the importance of giving due process to both plaintiff and defendant drug companies" and that " $[\mathrm{i}] \mathrm{n}$ the course of these settlement discussions, the court became fully aware of the contentions of all parties." 205

Even if Judge Weinstein was technically correct in refusing to disqualify himself in this case, a reader of his opinion may not attribute the defense motion to purely strategic behavior, as in so many such situations. For most litigants, expressions of sympathy and compassion for an adversary, given by the judge in a private meeting, suggest a disposition in that person's favor. Neither the existence of a record nor abstract bilateral references to due process and the parties' "contentions" are likely to dispel that impression. ${ }^{206}$

In denying the disqualification motion, Judge Weinstein relied on the fact that when he held the meetings in question, he was cooperating with a New York judge in an effort to settle New York state court DES

199. Cf. Weinstein, Mass Tort Litigation, supra note 4, at 160-62 (arguing that agency problems between lawyers and their clients in class action context may be no worse than in non-class action context).

200. Id. at 46 . For criticism of the word and its philosophical underpinnings, see Mullenix, supra note 4 , at 585-86.

201. Bilello v. Abbott Lab., 825 F. Supp. 475, 476 (E.D.N.Y. 1993).

202. Id. at 476 .

203. Id. at $48^{n}$.

204. See id. at 481.

205. Id. at 477 ("The detailed contentions of defendants as to the instant cases were presented forcefully.”).

206. Characteristically, Judge Weinstein recognizes the problem. See Weinstein, Mass Tort Litigation, supra note 4 , at 99 . 
cases. He justified the denial on the ground that quite different norms of judicial behavior are appropriate in the settlement role. ${ }^{207}$

The problems that active judicial involvement in settlement can pose for the parties and the judge in ordinary litigation include role confusion. ${ }^{208}$ The party that moved to disqualify Judge Weinstein may be forgiven for confusion about the role of an Article III judge in seeking to assist in the settlement of state court cases. Indeed, Judge Weinstein himself seems confused about that role, since his subsequent, extrajudicial, descriptions of the meetings that led to the disqualification motion suggest that they occurred after the participants' cases settled.209

Finally, attention to nontraditional forms of judicial communication should not obscure the fact that the traditional form of communication for a litigant who is aggrieved by an action of the trial court is an appeal.210

\section{Empathy. -}

The problem of empathy versus impartiality is not an easy one to resolve. Even in a medical model, empathy may be dangerous since subjectivity may interfere with dispassionate analysis and good judgment. The problems may be more difficult in the legal setting. Nevertheless, we must consider parting from a traditional model. ${ }^{211}$

As a professor, Jack Weinstein expressed the view that " $[t]$ he best judges depend far more on experience, ability, warmth of spirit, and compassion than they do on procedure." 12 As a judge, he has consistently maintained that " $[\mathrm{w}]$ ithout the ameliorating effect of a sensitivity to the needs of others, the law functions as a rapacious machine whose impartiality will ultimately consume us all." 13 Whether in handling social security disability appeals or in handling Agent Orange, Judge Weinstein has

207. See Bilello, 825 F. Supp. at 479-81.

208. See, e.g., Resnik, supra note 74, at 425-28.

209. In DES cases, with the assistance of a special master, hundreds of cases were settled. After the settlements, one judge sat down with many of the DES claimants and heard their harrowing stories. The ability to address the court, with a reporter present, seemed to provide a catharsis for those who believed themselves harmed by DES. Many of them complained that they could not get health insurance for themselves or their children; a class action would have provided for this contingency and other needs of the group.

Weinstein, Mass Tort Litigation, supra note 4, at 13 (emphasis added); see also id. at 99.

210. A process perspective on the motivation to appeal suggests that limiting access to appellate courts has worrisome implications for judicial legitimacy. See generally Scott Barclay, Posner's Economic Model and the Decision to Appeal, 19 Just. Sys. J. 77 (1997).

211. Weinstein, Mass Tort Litigation, supra note 4, at 99.

212. Weinstein, Trends, supra note 70, at 1445.

213. Weinstein, Justice and Mercy, supra note 141, at 820. Compare Judge Weinstein's view about social scientists: "The social scientist unrestrained by sympathy for human beings is a menace." Jack B. Weinstein, Hans Zeisel's Contributions to the Administration of Justice and the Sociology of Law, 41 U. Chi. L. Rev. 213, 222 (1974). 
followed Jerome Frank's refusal to accept injustice. ${ }^{214}$ He has not yet, however, provided the answer Frank was looking for when he asked "why our judges must continue to do merciful justice by stealth." $=15$

Judge Weinstein's commitments to access and communication enable him to maximize opportunities for empathy with those who are aggrieved, and the benefits and costs of his empathy are linked to, or reflect, the benefits and costs of those other two commitments. Expressions of empathy by a judge humanize what can be a bewildering and dehumanizing process and may help even those who are not successful in the legal process to feel that they have been fairly treated. ${ }^{216}$ Moreover, the capacity to experience and express empathy may well be important to a judge's performance, by enhancing not only that individual's personal satisfaction but also his or her creative contributions to the law.

There can be little doubt that Judge Weinstein's empathy for those who are aggrieved, whose access to the judicial process he has facilitated by enabling aggregation, and to whom he has reached out in communication, has caused him at times to depart from the law as it is generally understood. Thus, Judge Weinstein was "struck by the deep emotional underpinnings of the [Agent Orange] litigation." 17 Although he recognized that the "science did not support a viable cause of action," he could not for that reason "ignor[e] those cries from the heart for justice." 218 Indeed, his empathy for various communities of plaintiffs involved in mass tort litigation-from asbestos, to Agent Orange, to DES, to the Dalkon Shield-sometimes causes him to regard them all as "tort victims," even though some of them, as he admits, cannot recover under the existing substantive law. 219

From this perspective, empathy is critical to Judge Weinstein's departures from the law as it is generally understood, informing the "felt sense of appropriateness" to which he has referred.20(1) It helps to explain, although it renders no less subjective, a principle or standard that "turns on the individual judge's . . sympathies or 'sense of justice." '2ㅚ Moreover, it may suggest that the dichotomy between independence and ideology in the work of Jack Weinstein is false, because independence of a type is in fact the Judge's overriding ideology.

214. See Frank, supra note 4, at 389 ("Mercy, charity, compassionateness, respect for the unique attributes of the men and women who come before our trial courts . . would seem to be needed components of a civilized judicial process.").

215. Id.

216. Cf. Weinstein, Mass Tort Litigation, supra note 4, at 13, 99.

217. Id. at 11

218. Id. at 11, 95; see also id. at 85-86 (discussing Judge Weinstein's eff orts in forging Agent Orange settlement, despite poor proof of causation, between indeterminate classes of plaintiffs and defendants).

219. See id. at 148 .

220. Id. at 171 ; see also supra note 77 .

221. Weinstein, Jury Nullification, supra note 71 , at 246; see also supra text accompanying note 77 . 
Ronald Dworkin has suggested that "the conventional, instrumental defense of academic freedom" is insufficient, arguing that invasions of academic freedom offend an "ideal of ethical individualism" that is valued not just by academics but also by society. ${ }^{222}$ This ideal imposes on prof essors "an undiluted responsibility to the truth, and it is, in that way, the closest a professional responsibility can come to the fundamental ethical responsibility each of us has, according to the ideals of ethical individualism, to live our lives in accordance with our own felt convictions." ${ }^{2} 23$

Judge Weinstein has spent a great deal of time in recent years grappling with the ethical issues of those involved in mass tort litigation, including judges. ${ }^{224}$ Lacking clear and generally accepted ethical standards to use in considering departures from the law, ${ }^{225}$ and relying on his sense of responsibility "to the people and [his] conscience through the Constitution," 226 Judge Weinstein lives Dworkin's ethical individualism as a judge, having lived it as a professor.

\section{Conclusion}

It has been a privilege to engage the work, judicial and extrajudicial, of a person as bright, creative and committed to the highest ideals of our profession as Jack Weinstein, and equally a privilege to seek to understand and explain the influences that contribute to the judicial behavior of such a complex person. I am sure that I have done neither those influences nor Judge Weinstein justice.

For me both the bad news and the good are that Jack Weinstein is unique. The news is bad, because judges with any of his distinguishing qualities - his intellectual power, capacity for pragmatic innovation, and, yes, capacity for empathy-are rare. As our elected representatives leave (or commit) more of society's pressing problems to the courts, we shall

222. Ronald Dworkin, We Need a New Interpretation of Academic Freedom, in The Future of Academic Freedom, supra note 19, at 181, 187.

223. Id. at 189.

224. See, e.g., W'einstein, Mass Tort Litigation, supra note 4.

The challenge of ethics in mass tort cases can be met in either of two ways: we can fashion a new set of positive rules to apply in these cases, or we can institutionalize a practice of granting "variances," allowing workable relief from the ordinary operation of the positive law. In either case, we first must find a set of ethical principles to guide our selection of the rules or exceptions we will apply in practice.

Id. at 46 (footnote omitted); see also id. at 171 ("Ethical and legal norms out of touch with real life lead not to morality, but to hypocrisy, abuse, and waste.").

225. See supra text accompanying notes $71-80$.

226. See Weinstein, Nazis, supra note 57, at 1154 ; supra text accompanying notes 78 , 115. Judge Weinstein believes that "the highest traditions of humanity and personal responsibility . . . ought to characterize our office." Weinstein, Federal Sentencing Guidelines, supra note 143 , at 366 . 
need, and shall surely have difficulty finding, more judges with those qualities.

The news is good, but only in a perverse sense. We are hypocrites, refusing to give the courts the tools they reasonably need to solve the problems left (or committed) to their care, but insisting on the ideal-or is it the ideology-of the rule of law. ${ }^{227}$ But insist we must in order to preserve a system that, although grossly imperfect, still seems preferable to the alternatives.

The American Bar Association established a Commission on Separation of Powers and Judicial Independence, the immediate animating force behind which seems to have been attacks on the judiciary by members of the political branches. ${ }^{228}$ While the ABA Commission was deliberating, reports from Washington suggested that "judicial activism" was high on the agenda of members of both houses of Congress, some of whom apparently believe that impeachment is, after all, a suitable vehicle for the expression of profound disagreement with the substance of judicial decisions. ${ }^{229}$

One might respond to these critics of the federal judiciary that the real problem is "legislative activism," in the sense of knee-jerk political responses to serious social problems, many of which are then left in the lap of the courts. ${ }^{230}$ Or one might argue that the problem arises from "legislative paralysis,"-Congress's refusal both to do legislative work that needs to be done ${ }^{231}$ and to give the judiciary the means to do theirs. ${ }^{232}$ Neither is an adequate response.

They are not adequate at the practical level because members of the political branches have different utility functions than do federal judges, and the rules of the game they play, ${ }^{2} 33$ including their norms of accountability, do not put a high premium on rationality. When push comes to shove, they also hold most of the power, which is ultimately why the judiciary is the "least dangerous" branch, ${ }^{234}$ and also the most vulnerable. That is why I believe that if judicial disobedience and refusal to accept institutional accountability were more prevalent, Judge Weinstein's most

227. See The Rule of Law: Ideal or Ideology (Allan C. Hutchinson \& Patrick Monahan eds., 1987).

228. See John Gibeault, Taking Aim, A.B.A. J., Nov. 1996, at 50, 51. The Commission recently issued its report. See ABA Comm'n on Separation of Powers and Judicial Independence, An Independent Judiciary (1997) [hereinafter ABA Comm'n, An Independent Judiciary].

229. See, e.g., Bruce D. Brown, An Empty 12th Seat, Legal Times, Mar. 17, 1997, at 6; Bruce D. Brown, Right Refocuses Aim at Judiciary, Legal Times, Jan. 20, 1997, at 1; see also supra text accompanying note 41.

230. See Geyh, supra note 32, at 1227; William H. Rehnquist, 1995 Year-End Report on the Federal Judiciary, 19 Am. J. Trial Advoc. 491, 495-96 (1996).

231. See Weinstein, Mass Tort Litigation, supra note 4, at 104.

232. See Rehnquist, supra note 230, at 492-94.

233. See Posner, supra note 4, at 134.

234. The Federalist No. 78, at 465 (Alexander Hamilton) (Clinton Rossiter ed., 1961); see also Alexander M. Bickel, The Least Dangerous Branch (1962). 
cherished professional possession-his independence-would be at risk, and with it, the independence of the federal judiciary.

They are not adequate at the normative level because fidelity to the rule of law in a democracy requires that, in the end, the judiciary abide irrationality and irresponsibility in the political branches, unless it is manifested in behavior that the Constitution, fairly interpreted, reprehends.235 "Abide" does not mean accept without question, or for that matter, without insistence that legislative foolishness be clear for all to see. The need for more such questions-and answers-for a genuine dialogue among the three branches of the federal government, is urgent. ${ }^{236}$

Until that time, as always, the capacity of the judiciary to protect us from ourselves depends upon its institutional independence. And the maintenance of that precious gift from our forefathers requires that, in Franklin's words, federal judges "hang together." 237 Judges can be scholars, ${ }^{238}$ and Judge Weinstein remains one of our most interesting and provocative scholars on issues confronting the courts. But, as judges, they must surrender some of the intellectual autonomy of professors. That is one of the prices of donning a robe.

235. See Fallon, supra note 45, at 53-54.

236. See Stephen B. Burbank, Ignorance and Procedural Law Reform: A Call for a Moratorium, 59 Brook. L. Rev. 841, 842-43 (1993); Stephen B. Burbank, Implementing Procedural Change: Who, How, Why, and When?, 49 Ala. L. Rev. (forthcoming 1997). The ABA Commission on Separation of Powers and Judicial Independence has recommended that Congress consider establishing "a permanent National Commission on the Federal Courts," a primary purpose of which would be to "facilitate nonconfrontational communication among the branches." See ABA Comm'n, An Independent Judiciary, supra note 228, at 54.

237. "We must all hang together, or assuredly we shall all hang separately." Benjamin Franklin, Remarks at the signing of the Declaration of Independence (July 4, 1776), in John Bartlett, Familiar Quotations 348 (14th ed. 1968).

238. But see supra note 113 (quoting Weinstein, Social Security Disability Cases, supra note 65 , at 897 ) (“Judges cannot be scholars."). 